\title{
Spatial Analysis and Modelling of Wind Farm Site Suitability in Nasarawa State, North-Central Nigeria
}

\author{
Chukwunonso Emmanuel Ozim ${ }^{*}\left(\mathbb{0}\right.$, Anita Odionyenfe Nweke², Salamatu Abraham Ekpo ${ }^{3}$, \\ Olufemi Stephen Oladeinde4, Haruna Kuje Ayuba ${ }^{3}$, Udochukwu Michael Mbanaso ${ }^{5}$ \\ ${ }^{1}$ GIS Unit, Enugu Electricity Distribution Company, Enugu, Enugu State, Nigeria \\ ${ }^{2}$ Federal Ministry of Mines and Steel Development, Abuja, FCT, Nigeria \\ ${ }^{3}$ Department of Environmental Management, Faculty of Environmental Science, Nasarawa State University, Keffi, Nigeria \\ ${ }^{4}$ National Space Research and Development Agency, Obasanjo Space Centre, Abuja, FCT, Nigeria \\ ${ }^{5}$ Department of Urban and Regional Planning, Faculty of Environmental Science, Nasarawa State University, Keffi, Nigeria \\ Email: *nuelsokky@gmail.com
}

How to cite this paper: Ozim, C.E., Nweke, A.O., Ekpo, S.A., Oladeinde, O.S., Ayuba, H.K. and Mbanaso, U.M. (2021) Spatial Analysis and Modelling of Wind Farm Site Suitability in Nasarawa State, North-Central Nigeria. Journal of Geographic Information System, 13, 603-630. https://doi.org/10.4236/jgis.2021.135033

Received: September 14, 2021

Accepted: October 25, 2021

Published: October 28, 2021

Copyright $\odot 2021$ by author(s) and Scientific Research Publishing Inc. This work is licensed under the Creative Commons Attribution International License (CC BY 4.0).

http://creativecommons.org/licenses/by/4.0/

\begin{abstract}
There has been an increasing global and local interest in developing renewable, clean, and cheap energy towards achieving Goal number 7 of the Sustainable Development Goals (SDG). However, decisions involving suitable and sustainable locations for renewable energy projects remain an important task. This study employed Geographic Information System (GIS) and Multi-Criteria Decision Analysis (MCDA) to spatially analyze and model wind farm site suitability in Nasarawa State. The aim is to integrate the environmental, social, and economic aspects of decision-making for identifying sustainable wind farm sites. The study distinguished between two sets of decision criteria: decision constraints and decision factors. The former defined the exclusion zones while the latter were standardized based on fuzzy logic to depict varying degrees of suitability across the State. The MCDA applied the weighted linear combination method, with relative weights generated through pairwise comparisons of the analytic hierarchy process to analyze three policy scenarios: equal weights, environmental/social priority, and economic priority scenario. A combination of resulting composite maps from the constraints and the factors gave the final suitability maps. The resulting suitability index (SI) for the respective policy scenario describes the degrees of suitability: Ideal locations were denoted by one (1) and the not suitable locations by zero (0), with values in-between depicting varying degrees of wind farm site suitability. Based on the SI, priority locations indicating areas with good prospects, in addition to the most suitable parcels of land, were identi-
\end{abstract}


fied and delineated. The composite decision constraint revealed that wind farm projects would not be viable in more than half $(57.58 \%)$ of the State. Wind speed was the major constraint and accounted for the exclusion of $46.25 \%$, with a mean fuzzy membership value of 0.2008 indicating low suitability across the State. Also, the average acceptable wind farm location for the three-policy scenario was $33.33 \%$ of the entire study area. Lafia, Obi, Keana, Awe, Nasarawa-Eggon, Wamba and Kokona LGAs were the identified priority Local Government Areas (LGAs). However, only Lafia, Obi, and Nasarawa-Eggon were consistent with changes in the policy objectives. All the priority LGAs have one or more of the most suitable parcels within their administrative boundaries except for Wamba. Despite the severe limitations of wind speed, substantial parts of Nasarawa State still provide great development potentials for wind energy. The "most suitable" locations in Lafia, Nasarawa-Eggon, and Obi LGAs should have first consideration for the development of wind energy in the State.

\section{Keywords}

GIS Multi-Criteria, Spatial Analysis and Modelling, Wind Energy Farm, Site Suitability, Nasarawa State Nigeria

\section{Introduction}

Nowadays, the increasing human population across the globe is exerting undue pressure on available non-renewable sources of energy known for their fast depletion and environmental degradation. Hence a shift of attention towards renewable and clean sources of energy by many national governments. Such sources include the wind, which has begun to take a high position in the global dialogue about energy production. A big question to profiting from the wind as a source of energy borders on identifying the most suitable location/s for wind farm construction, with respect to achieving the highest possible rates of sustainable electricity production.

Wind energy is considered one of the eco-friendliest and economically viable forms of renewable energy [1]. [2] stated that the expansion of wind farm developments could serve as a fundamental aspect in climate change mitigation and help reduce greenhouse gas emissions. According to [3], wind energy is among the lowest impact forms of electricity generation in terms of its benefits outlined at the regional and global level; it is neither associated with air nor water pollution, and operational costs are practically zero after building a turbine.

Although Africa is top-ranked as having the world's highest reserves of renewable energy sources [4], there have been reports of underutilization of wind as a renewable energy source in West Africa, most especially in Nigeria [5]. Research findings and wind data from Nigerian Meteorological Agency have shown that wind speed of about 8.07 meters per second $(\mathrm{m} / \mathrm{s})$ could be harnessed in the northern parts of Nigeria to provide enough energy for daily needs 
[6]. This gap between potential and extent of exploitation poses questions about barriers to wind energy development in Africa and Nigeria, in particular.

However, a laudable interest in wind energy is currently on the rise across the continent and several countries including Nigeria have planned installations of wind power. The Nigerian Renewable Energy Master Plan (REMP) seeks to increase the supply of renewable electricity from $13 \%$ of total electricity generation in 2015 to $23 \%$ in 2025 and $36 \%$ by 2030 [7]. In view of achieving this, it becomes imperative to spatially analyse the potential in renewable energy sources such as Wind, Waves, Solar, Tides, and Geothermal.

To make wind farm installations sustainable, it must possess characteristics that make its operation technically and economically feasible, and at the same time guarantee preservation of environmental and social values [8]. There has been a dearth of information in this regard for most parts of Nigeria. Thus, this study incorporated Multi-Criteria Decision Analysis into Geographical Information System (GIS) to spatially analyse and model site suitability for wind farm development in Nasarawa State, Nigeria.

\section{Materials and Methods}

\subsection{Study Area}

Nasarawa State occupies the space between latitudes $7^{\circ} 45^{\prime} 00^{\prime \prime}$ and $9^{\circ} 35^{\prime} 00^{\prime \prime}$ of the Equator and longitudes $6^{\circ} 45^{\prime} 03^{\prime \prime}$ and $9^{\circ} 45^{\prime} 03^{\prime \prime}$ of the Greenwich Meridian in the basement complex of North-central Nigeria. The State spans a total area of about 26,562.36 square kilometers and stands at an altitude of 400 meters above sea level. Nasarawa State shares a border with Kaduna State in the North; Federal Capital Territory (FCT) to the west, Kogi and Benue to the south, and Taraba and plateau to the east. The State is made-up of thirteen Local Government Area (LGA), namely: Karu, Keffi, Kokona, Nasarawa and Toto in the West Senatorial District; Akwanga, Nasarawa-Eggon and Wamba in the Northern District and Lafia, Keana, Doma, Awe and Obi in the Southern District [9]. The climate of Nassarawa State is typical of a tropical sub-humid climate having two distinctive seasons. The rainy season sets in from about the beginning of May and lasts until October. The dry season spans between November and April. The average hourly wind speed in Nasarawa experiences mild seasonal variation over the year. The windier part of the year lasts for about nine months, usually from $2^{\text {nd }}$ September to $30^{\text {th }}$ November. Figure 1 presents a map of Nasarawa State depicting its thirteen Local Government Areas (LGA), and Figure 2 shows the wind speed characteristics.

\subsection{Sources of Datasets and Collection Methods}

This study integrated Multi-Criteria Decision Analysis (MCDA) into Geographic Information System to develop decision support models for identifying potential sites for wind energy farm development in Nasarawa State. The MCDA applied Weighted Linear Combination (WLC) method using the criteria weights 


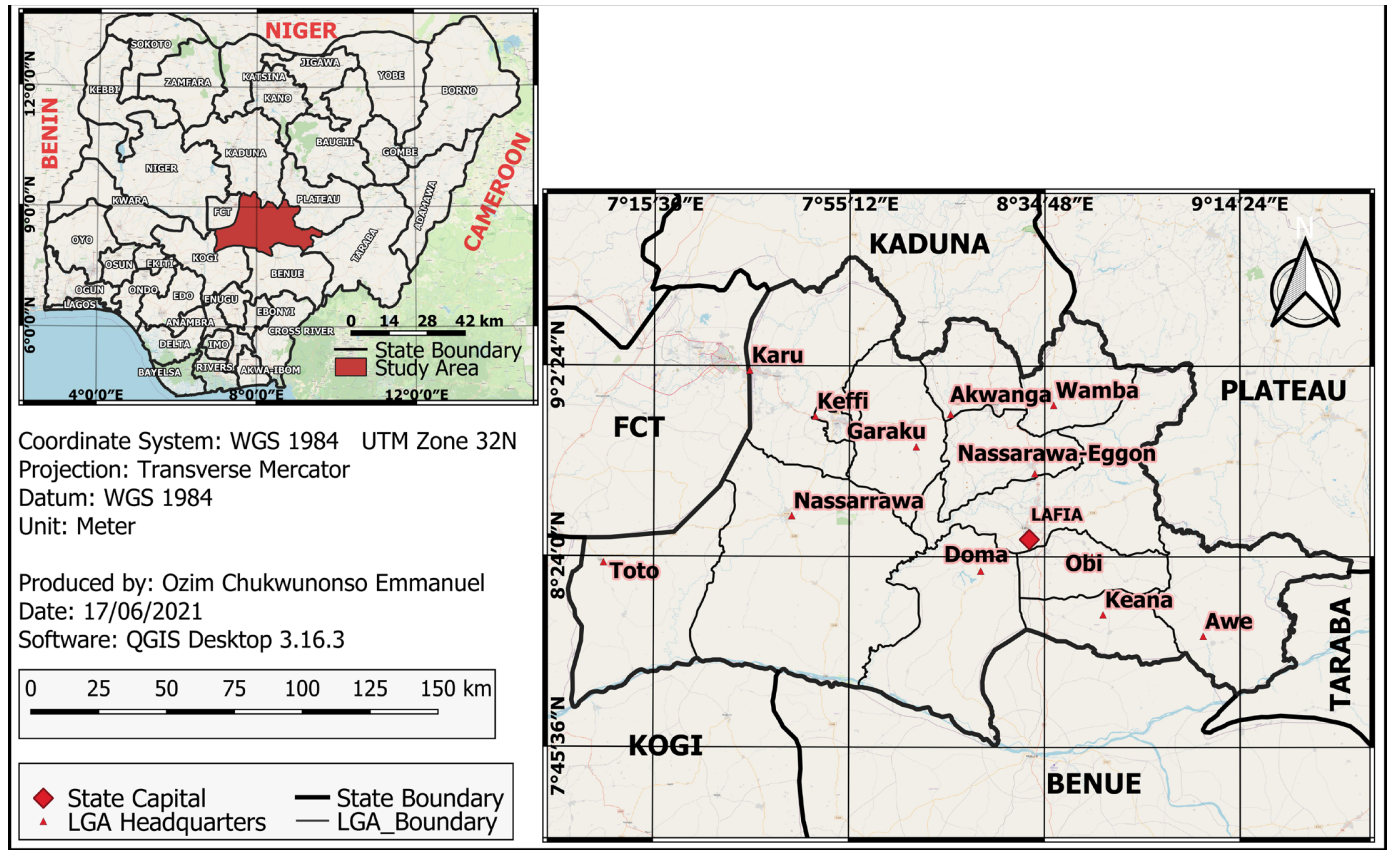

Figure 1. Nasarawa State showing the 13 LGA.

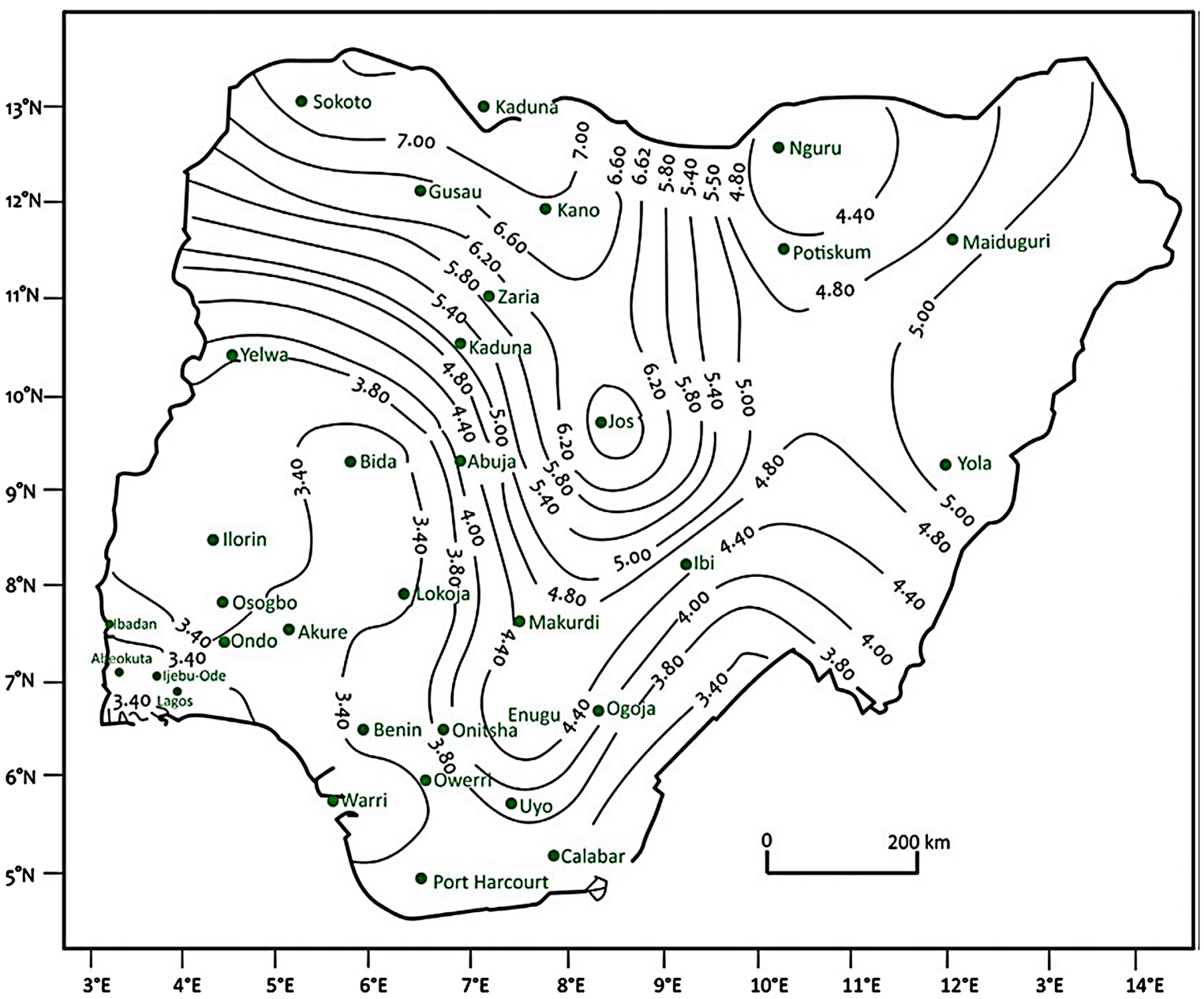

Figure 2. Isovents in ms determined from 40 years' measurements at $10 \mathrm{~m}$ height [5]. 
(relative importance) generated through the Analytical Hierarchy Process (AHP). The criteria include environmental, social, and economic aspects of wind farm development that describe specific geographical constraints or advantages in the study area. Review of existing literature [1] [8] [10] [11] and [12] and information from the Nasarawa State Urban Development Board (NAUPDB) aided the criteria selection. The spatial formats (such as: shapefiles, raster and NetCDF) of the identified criteria were acquired and used as datasets for the study.

The datasets are publicly available and accessible from various secondary sources of data collection. The number of features included in the set of assessment criteria was based on data availability and regarded as suitable according to [13]. They submitted that the number of criteria should be kept minimal or as small as possible. Nevertheless, the addition of numerous other features could improve the quality of the study's result. Among the datasets considered in this study are wind speed (at $50 \mathrm{~m}$ ); slope; Land cover/Land use; forest reserves; wetlands; inland waterbodies; transmission network; road network; railway network; town/populated places (settlement points) and the administrative area of the state.

Data on forest reserves, wetlands, and inland waterbodies constituted the ecologically significant areas. Road and rail networks formed the safety restriction. Table 1 shows a summary of the datasets used in this study with their respective method of acquisition.

Table 1. Summary of datasets, sources, and methods of collection.

\begin{tabular}{|c|c|c|c|}
\hline S/N & Dataset & Source & Method of Collection \\
\hline 1 & Wind Speed & $\begin{array}{l}\text { United States National Air } \\
\text { Space Agency (NASA) website }\end{array}$ & $\begin{array}{l}\text { Wind speed layer at } 50 \mathrm{~m} \text { height was downloaded in Netcdf format, values were } \\
\text { extracted to randomly created points and interpolated. }\end{array}$ \\
\hline 2 & Slope & $\begin{array}{l}\text { United State Geological Survey } \\
\text { (Shuttle Radar Topographical } \\
\text { Mission) DEM }\end{array}$ & Slope layer was extracted from the DEM. \\
\hline 3 & $\begin{array}{l}\text { Transmission } \\
\text { Network }\end{array}$ & World Bank Data Catalog & $\begin{array}{l}\text { Zipped shapefile of Nigerian Electricity Transmission Network was downloaded for } \\
\text { http://datacatalog.worldbank.org/dataset/nigeria-electricity-transmission-network. }\end{array}$ \\
\hline 4 & $\begin{array}{l}\text { Road and Railway } \\
\text { Network }\end{array}$ & DIVA-GIS & $\begin{array}{l}\text { Shapefile of the road network within the study area was downloaded from diva-gis } \\
\text { online (https://www.diva-gis.org/gdata) and the railway was digitized from existing } \\
\text { hardcopy map. }\end{array}$ \\
\hline 5 & $\begin{array}{l}\text { Ecologically } \\
\text { Significant Areas }\end{array}$ & $\begin{array}{l}\text { Nasarawa Geographic } \\
\text { Information Service (NAGIS) }\end{array}$ & $\begin{array}{l}\text { Hardcopy map of Nasarawa state forest reserves was obtained and georeferenced } \\
\text { and the existing reserves and wetlands were digitized from the it. }\end{array}$ \\
\hline 6 & Land cover/use & NAGIS & Softcopy map of latest (2019) land cover/use map of the State was obtained. \\
\hline 7 & Settlement Points & DIVA-GIS & $\begin{array}{l}\text { Gazetteer of places was downloaded and XY coordinates were added to the study } \\
\text { area and exported as shapefiles. }\end{array}$ \\
\hline 8 & Inland water (rivers) & DIVA-GIS & $\begin{array}{l}\text { Inland water layer (shapefile) was downloaded from diva-gis online } \\
\text { (https://www.diva-gis.org/gdata). }\end{array}$ \\
\hline 9 & Administrative Map & DIVA-GIS & Downloaded from diva-gis online (https://www.diva-gis.org/gdata). \\
\hline
\end{tabular}




\subsection{Analysis Procedure}

Data analysis was based on MCDA and performed in ArcGIS 2.2 Desktop Advanced software. Various methods of MCDA have been computed for both commercial and free, open-source GIS and applied in recent studies. [14] [15] identified these methods to include deterministic, probabilistic, and fuzzy-based multi-attribute and multi-objective techniques. Among the multi-attribute methods such as the: Boolean operator overlay, Weighted Linear Combination (WLC), Ordered Weighted Averaging (OWA), concordance analysis, and ideal point method. The first two are often used in site selection studies or suitability analysis [14] [16]. These methods have developed from the original map overlay concept by McHarg [17]. However, Boolean operators' procedures can only identify areas, which instantaneously satisfy the specified criteria. Consequently, supplementary procedures based on the MCDA methods such as the ones listed above are required to assess the suitability of sites and generate rankings of locations that depict their attractiveness [18].

Thus, to complement the Boolean-based procedure, which uses decision constraints, this study adopted the WLC techniques to generate/compile an overall suitability index (SI) for the study area. Every individual grid-cell depicted a composite degree of wind farm site suitability. Following aggregation of the decision factors, the exclusion zones (unfeasible areas) were integrated by multiplying the suitability index maps with the composite constraint map.

Pre-processing of datasets was carried out in the ArcGIS environment. Using the ArcGIS projection tool, we converted the acquired datasets from Geographic Coordinate System (GCS) to a Projected Coordinate System (PCS). The projection enabled linear measurements such as distance and area calculations. Furthermore, we resampled the datasets into the same cell size and corrected the geometric problems in the data. In line with planning "setback" standards acquired from NAUPDB and existing literature for wind farm developments, restriction/constraint model (decision constraint), suitability model (decision factors), and a final suitability model (restriction plus suitability) were developed for the study.

The restriction model shows locations where wind farm development can (feasible) and cannot be (unfeasible) allowed. In contrast, the suitability model explored the varying degrees of suitability across the study area, and the final model handled the identification of priority LGA and most suitable locations. The study investigated three policy priority scenarios (equal weights, environmental/social priority, and economic priority scenario). In scenario 1 , all the decision factors were assigned equal weights of 0.1667 (1/6), simulating equal importance. Conversely, in scenarios 2 and 3, the criteria weights were obtained by applying the analytic hierarchy process (AHP) based on the pairwise comparison of the relative importance of decision factors.

According to [19], the AHP is a commonly applied method in multi-criteria decision making, which uses a pairwise comparison approach (PWCA) to de- 
termine the weightage of the decision factors. Weights are derived based on the input by the user in terms of the relative importance of criteria, for example, how important is criteria " $A$ " in comparison to criteria " $B$ ", "C", " $D$ " etc. Its ability to convert subjective assessments to a set of overall weights was deemed appropriate for this study. AHP is designed to numerically evaluate the relative power of alternative factor(s) to achieve the overall goal [20]. In this study, we entered literature-based values of the relative importance of the decision factors into ArcGIS AHP extension 2.0 to obtain their corresponding weights.

We applied the nine-point continuous scale (Table 2) to determine the AHP pairwise comparisons values, and the results were recorded in a matrix as introduced by [21]. The AHP also provides a mathematical measure for checking inconsistency of judgments by calculating a consistency ratio (CR), where a CR value below 0.1 is considered acceptable [20].

Matrices of pairwise comparisons and associated weights for Scenarios 2 and 3 are presented in Table 3 and Table 4. Pairwise assessments were consistent in scenarios I and 2, with CR values of 0.013 and 0.018 , respectively. Also, a summary of weights associated with the respective decision factors for the three policy scenarios is presented in Table 5.

\subsubsection{Decision Constraints}

In line with the standards and procedures presented in Table 6 and Figure 3, we

Table 2. Scales of AHP pairwise comparisons.

\begin{tabular}{cl}
\hline Intensity of Importance & \multicolumn{1}{c}{ Description } \\
\hline $\mathbf{1}$ & Equal importance \\
$\mathbf{3}$ & Moderate importance of one factor over another \\
$\mathbf{7}$ & Strong or essential importance \\
$\mathbf{9}$ & Very strong or demonstrated importance \\
$\mathbf{2 , 4 , 6 , 8}$ & Extreme importance \\
Reciprocals & $\begin{array}{l}\text { Values of inverse comparison: if factor } \mathrm{z} \text { has one of the above numbers } \\
\text { assigned to it when compared with factor } \mathrm{y}, \text { then a reversed comparison } \\
\text { means that y would have the reciprocal. }\end{array}$
\end{tabular}

Source: [21].

Table 3. Matrix of pairwise comparison and weights of factors for scenario 2 .

\begin{tabular}{cccccccc}
\hline & F1 & F2 & F3 & F4 & F5 & F6 & Weights \\
\hline F1 & $*$ & 3 & 3 & 3 & $1 / 5$ & $1 / 3$ & 0.11766 \\
F2 & $1 / 3$ & $*$ & 1 & 1 & $1 / 9$ & $1 / 5$ & 0.04638 \\
F3 & $1 / 3$ & 1 & $*$ & 1 & $1 / 9$ & $1 / 5$ & 0.04639 \\
F4 & $1 / 3$ & 1 & 1 & $*$ & $1 / 9$ & $1 / 5$ & 0.04639 \\
F5 & 5 & 9 & 9 & 9 & $*$ & 3 & 0.50379 \\
F6 & 3 & 5 & 5 & 5 & $1 / 3$ & $*$ & 0.23939
\end{tabular}


Table 4. Matrix of pairwise comparison and weights of factors for scenario 3.

\begin{tabular}{cccccccc}
\hline & F1 & F2 & F3 & F4 & F5 & F6 & Weights \\
\hline F1 & $*$ & 4 & 4 & 6 & 9 & 6 & 0.48636 \\
F2 & $1 / 4$ & $*$ & 1 & 3 & 6 & 3 & 0.17465 \\
F3 & $1 / 4$ & 1 & $*$ & 3 & 6 & 3 & 0.17468 \\
F4 & $1 / 6$ & $1 / 3$ & $1 / 3$ & $*$ & 2 & 1 & 0.06485 \\
F5 & $1 / 9$ & $1 / 6$ & $1 / 6$ & $1 / 2$ & $*$ & $1 / 2$ & 0.03462 \\
F6 & $1 / 6$ & $1 / 3$ & $1 / 3$ & 1 & 2 & $*$ & 0.06484 \\
\hline
\end{tabular}

Table 5. Summary of decision factors' weights.

\begin{tabular}{lccc}
\hline \multicolumn{1}{c}{ Decision Factor } & $\begin{array}{c}\text { Scenario 1 } \\
\text { Equal Weights }\end{array}$ & $\begin{array}{c}\text { Scenario 2 } \\
\text { Environmental-Social } \\
\text { Priority }\end{array}$ & $\begin{array}{c}\text { Scenario 3 } \\
\text { Economic } \\
\text { priority }\end{array}$ \\
\hline F1: Wind Speed & 0.16667 & 0.11766 & 0.48636 \\
F2: Slope & 0.16667 & 0.04638 & 0.17465 \\
F3: Land cover/land use & 0.16667 & 0.04639 & 0.17468 \\
F4: Proximity to transmission network & 0.16667 & 0.04639 & 0.06485 \\
F5: Proximity to road network & 0.16667 & 0.50379 & 0.03462 \\
F6: Distance from ecologically & & & 0.06484 \\
significant areas & 0.16667 & 0.23939 & \\
\hline
\end{tabular}

Table 6. Summary of decision constraints employed in this study.

\begin{tabular}{cccc}
\hline Constraint & Type & Standard & Sustainability Sector \\
\hline C1 & Wind speed & Wind speed $\geq 4.5 \mathrm{~m} / \mathrm{s}$ & Economic \\
C2 & Settlement/Built-up areas & Built-up areas $>2000$ & Social \\
& & Forest reserves $>1000$ & \\
C3 & Environmental protection & Wetlands $>1000$ & Environmental and social \\
& & Inland waters $>400$ & \\
& & Road network $>500$ & Social (Public safety) \\
\hline
\end{tabular}

Source: Adapted from [10].

created Boolean-based map layers for each decision constraint. Unfeasible areas were assigned zero value (0) and all other locations a value of one (1). Furthermore, we multiplied/overlayed the respective decision constraint maps to generate a composite constraint map. The resulting hybrid map details the exclusion zones (unfeasible areas) assigned a value of zero (0), as well as potential development sites (feasible areas) denoted with one (1). The standards followed in creating the individual decision constraint's map layers are described as follows:

Wind resource is often a crucial consideration in assessing optimal locations for wind farm development: the better the resource, the more promising for potential power generation and project revenue [22]. According to [2] and the 


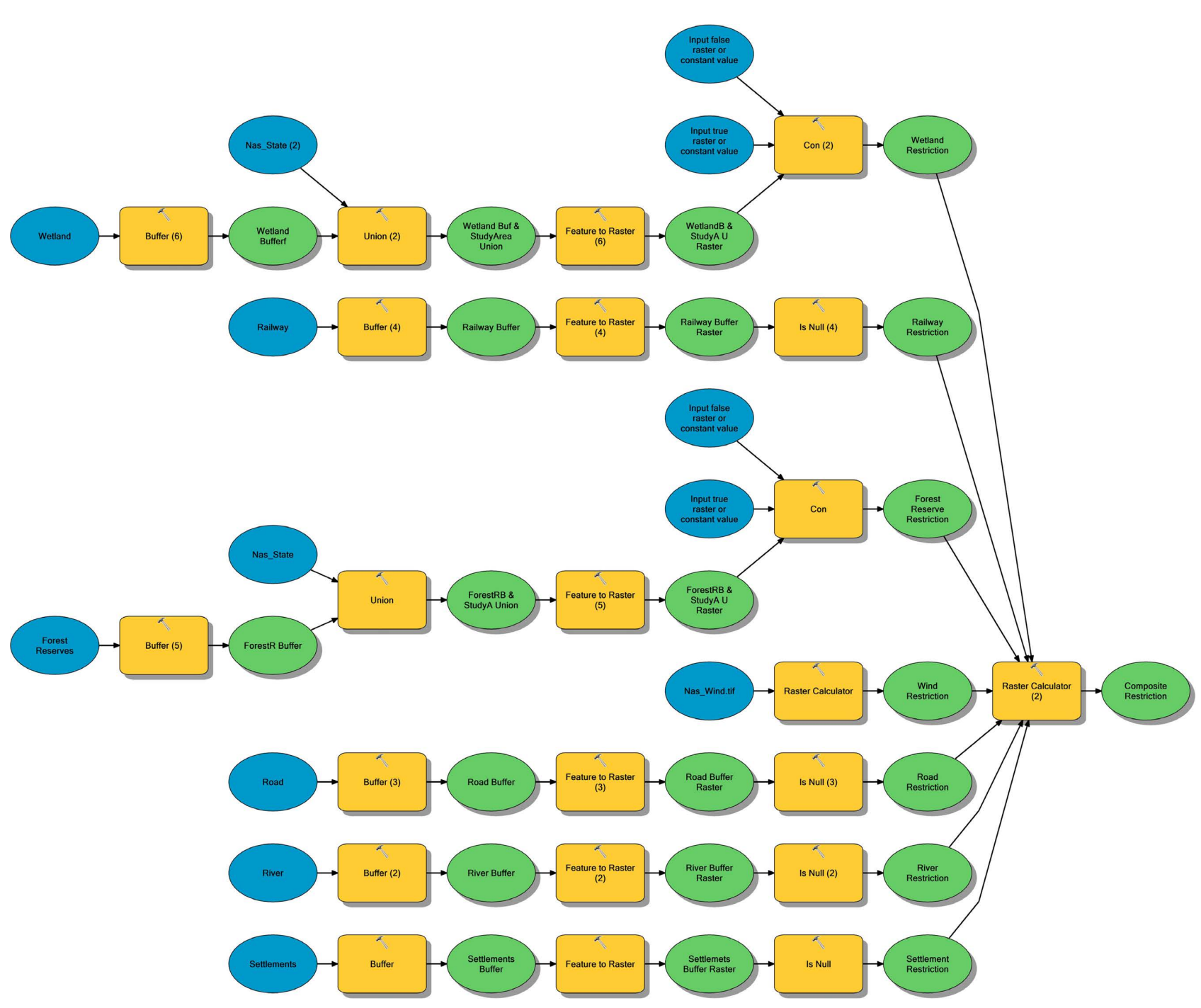

Figure 3. Restriction model.

[23], wind turbines generally begin to produce electricity at about $3-4 \mathrm{~m} / \mathrm{s}$; nevertheless, existing scientific publications usually apply a threshold value of $4.5 \mathrm{~m} / \mathrm{s}$ [1] or $5.0 \mathrm{~m} / \mathrm{s}$ [8]. In this study, locations with wind speed lower than $4.5 \mathrm{~m} / \mathrm{s}$ were considered unfeasible for wind farm development and thus excluded.

A host of parameters require an evaluation before sitting wind farms nearby urban/populated areas. Existing scholarly articles put various setback distances from built-up areas and settlements in the range of 500 to $2000 \mathrm{~m}$, contingent on the type of area (large city, town, for example.) or residents' population [1] [8] [10] [22] [24]. These publications describe that further assessment in the context of visual amenity, blade glint, shadow flicker and reflections, health issues, and noise are required for any wind farm development proposal within a $2000 \mathrm{~m}$ range from existing residences. Hence, this study considered built-up areas (comprising towns and populated places) in addition to a $2000 \mathrm{~m}$ buffer unfeasible for wind farm development. 
Developing wind farms in protected areas like national parks, nature reserves, or state conservation areas endanger the natural environment [10]. In the study of [8], they pointed out that a $1000 \mathrm{~m}$ buffer around areas of ecological value should be applied, in addition to a $400 \mathrm{~m}$ buffer from water bodies. Therefore, our study created a $400 \mathrm{~m}$ buffer around the inland waters (constituting significant rivers and lakes) and a $1000 \mathrm{~m}$ buffer around other ecologically essential areas (forest reserves and wetlands). All the regions within the buffer were deemed unfeasible for wind farm development and hence excluded.

Furthermore, it is unsafe to situate wind farms too close to infrastructures like road and rail networks and airports. Hence, several safety distances have been applied in previous studies ranging from $150 \mathrm{~m}$ as the minimum for roads and rail networks [1] [24] to $500 \mathrm{~m}$ [10] [25]. Roads (single/dual carriageway: federal or state) and rail network, together with a buffer of $500 \mathrm{~m}$, were considered not unfit for wind farm development and thus excluded.

\subsubsection{Decision Factors}

The decision factors were mainly standardized through the application of fuzzy sets theory. The fuzzy set theory acknowledges the possibility of having multiple groups simultaneously with the degree of each group described as a membership value. It plays a significant role in handling uncertainty by allowing the 'grouping of individuals into classes without sharply defined boundaries, which is suitable when describing "ambiguity, vagueness, and ambivalence in models of empirical phenomena" [24]. In the fuzzy set's theory, the degree of membership of an item $p$ in a fuzzy subset $P$ is defined in the range of membership value of zero (0) and one (1) through the application of a membership function (MF) [26]. Although several types of membership functions exist for describing fuzzy sets, this study adopted the linear process. The process was considered fitting for representing the varying degrees of site suitability at varying distances from features defined in the deciding factors. Furthermore, a linear function was also adopted in similar studies by [1] [10] and [24].

Also, two types of linear functions, namely: increasing fuzzy membership function (IFMF) and decreasing fuzzy membership function, were used in this study. In the former case, higher values of $\boldsymbol{p}$ in a given subset $\mathbf{A}$ are regarded more suitable than lower values in $p$. For instance, the higher the wind speed, the more suitable the location. For the latter, lower values indicate higher suitability, i.e., the lower the slope, the more suitable the location. A membership function is associated with two threshold values/control points: $\boldsymbol{q}$ indicating the least suitable value of $\mathbf{A}$, where the grade of membership is not satisfied and hence has a membership value equal to zero (0); and $\boldsymbol{p}$ indicating the value of $\mathbf{A}$ where the grade of membership is fully satisfied and hence has a membership value equal to one (1).

We created a standardized map layer for the respective decision factors, specifying the membership grade in the range of zero (0: not gratified) and one (1: fully gratified). Therefore, a membership grade or value of zero (0) stands for 
not suitable location (grid cell) and a value of one (1) an optimal/most suitable location. Also, we generated Euclidean Distance map layers for some decision factors before there standardization. The "Euclidean Distance" tool in the ArcGIS Spatial Analyst toolbox enabled the process. For decision factor F6 (Land cover/use), we used the lookup tool to assign membership values to the individual classes/categories in the attribute table, and a layer with new cell values was generated. Table 7 presents the threshold values used to standardize each decision factor, and Figure 4 shows the suitability model. The decision factors are described as follows:

Decision factor F1 describes the site suitability of the study area for wind energy farm with respect to wind speed. This factor assumed an Increasing Fuzzy Membership Function (IFMF). The least suitable threshold value (q-value) was set to a wind speed value of $4.5 \mathrm{~m} / \mathrm{s}$ in accordance with the associated decision constraint $\mathrm{C} 1$. The most suitable threshold value (p-value) was set to $6.53 \mathrm{~m} / \mathrm{s}$, considering the wind speed range of the study area $(3.02-6.53 \mathrm{~m} / \mathrm{s})$.

We used the Decision factor F2 to create a representation of the varying degree of site suitability with respect to prevailing slope gradient. It assumed a Decreasing Fuzzy Membership Function (DFMF). Varying threshold values for slope gradient exist in previous scientific publications. According to [8], a questionnaire aiming relevant public and private sectors in the UK discovered that wind farm areas must have a slope angle less than 10 percent. However, higher thresholds have been applied by some other studies such as [1] who used a q-value of 20 percent for their fuzzy membership function. considering both the

Table 7. Summary of decision factors employed in this study.

\begin{tabular}{|c|c|c|c|c|c|c|}
\hline Factor & Type & MF type/value & Unit & q-value & p-value & Sustainability Sector \\
\hline F1 & Wind speed & IFMF & $\mathrm{m} / \mathrm{s}$ & 4.5 & 6.53 & Economic and Environmental \\
\hline F2 & Slope gradient & DFMF & $\%$ & 15 & 2 & Economic and Environmental \\
\hline F3 & Proximity to transmission network & DFMF & $\mathrm{m}$ & 100,000 & 100 & Economic \\
\hline F4 & Proximity to road network & DFMF & $\mathrm{m}$ & 10,000 & 500 & Economic \\
\hline F5 & Distance from ecologically significant areas & IFMF & $\mathrm{m}$ & 1000 & 5000 & Environmental and Social \\
\hline \multirow[t]{10}{*}{ F6 } & Land cover/use (qualitative variables) & N/A & & & & Economic and Environmental \\
\hline & Agriculture & 0.8 & & & & \\
\hline & Grassland & 1 & & & & \\
\hline & Heavy forest & 0 & & & & \\
\hline & Light forest & 0 & & & & \\
\hline & Waterbody & 0 & & & & \\
\hline & Rock outcrop & 0.6 & & & & \\
\hline & Open space & 0.8 & & & & \\
\hline & Pit & 0 & & & & \\
\hline & Urban area & 0.2 & & & & \\
\hline
\end{tabular}

Source: Adapted from [10]. 


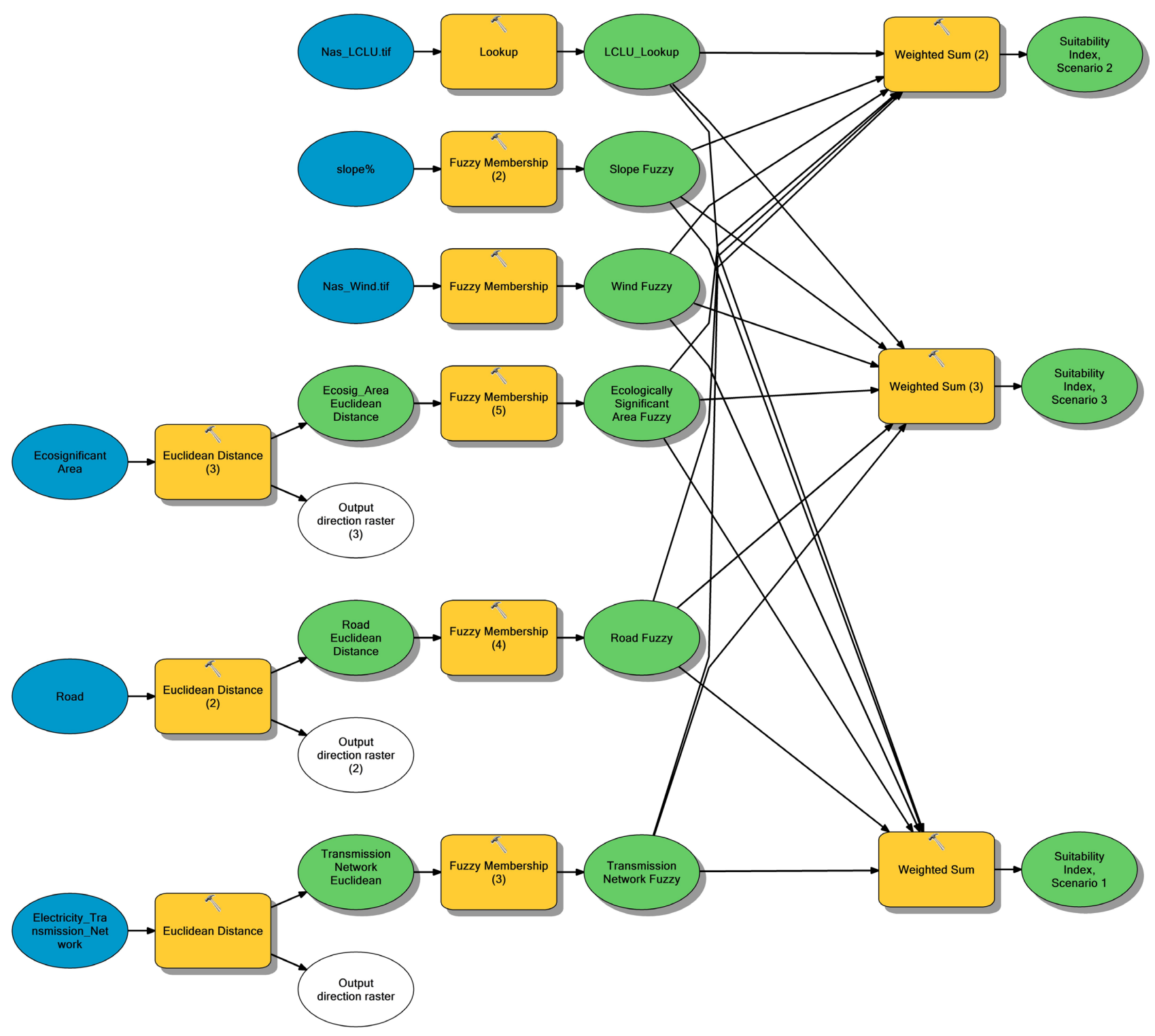

Figure 4. Suitability model.

economic feasibility (accessibility) and the minimisation of potential environmental impacts from erosion and soil loss, we applied a q-value of 15 percent for slope gradient and a p-value of 2 percent.

Energy generated by wind turbines is transmitted to the end users through a transmission/interconnection facility. Three types (transmission, distribution and direct connection to delivery point) of electricity network often serve this purpose depending on the voltage level of the generated electric-power [27]. We used Decision factor F3 to symbolise site suitability with respect to proximity to the national transmission network, based on a DFMF. From an economic viewpoint, [8] stated that wind farms must not be located further than 10,000 m away from the grid; yet, not closer than $100 \mathrm{~m}$. In this study, the q-value and p-value for decision factor F3 were set to 10,000 m and $100 \mathrm{~m}$, respectively.

Decision factor F4 was used to symbolise the site suitability with respect to 
proximity to road network (including highways, secondary roads and minor roads), based on a DFMF. According to [8] [10], the location of wind farms should not be further than $10,000 \mathrm{~m}$. This will enable easy access, and reduce the cost of construction and maintenance. Hence, we adopted 10,000 $\mathrm{m}$ as the $\mathrm{q}$-value for decision factor F4, and $500 \mathrm{~m}$ for the p-value (in accordance with decision constraint $\mathrm{C} 4$ ).

The site suitability with respect to distance from ecologically significant areas was denoted decision factor F5 (IFMF). [10] suggested that in order to mitigate negative environmental impacts, it is suitable to assign a higher membership value to places further away from ecologically significant areas. In the study of [12], a p-value of $5000 \mathrm{~m}$ was considered to be appropriate in their fuzzy set for protection of bird habitat. Hence, in this study, a q-value of $1000 \mathrm{~m}$ was set for decision factor F5 in line with the buffer distance defined under decision constraint C3, and the p-value was set to $5000 \mathrm{~m}$.

Decision factor F6 represents the suitability of the study area with respect to the qualitative attribute of land cover/use. We indexed the nine (9) land cover/use classes of the study area using a Likert-type scale ranging from zero (0) to one (1) in a similar approach to the study of [10] and [1]. We evaluated the site suitability with reference to land cover/use based primarily on tree density. Higher density indicates greater environmental impact [28], clearing costs for developers [29], as well as risks of nearby vegetation affecting the wind speed and direction of flow [8].

Furthermore, to make statistical analysis possible, we reclassified the suitability index for each of the three policy scenarios to conform with the suitability classes described in Table 8. After the reclassification, we calculated the total area for the respective suitability class in each policy scenario. The areas deemed "satisfactory/acceptable" for wind farm development were defined based on the lower SI score of the "moderate suitability" class and hence described with the following suitability index score interval: $0.50<\mathrm{SI} \leq 1$.

We identified and delineated "priority areas", defined in this study as fascinating areas for further investigation by generating statistics for the suitability classes across the 13 LGA of the State. Then the six LGA that showed the highest prospect for wind farm development under each policy scenario were identified. We achieved this by comparing the percentage of land classified as "high suitability" (SI > 0.75) with the total administrative area of each Local Government

Table 8. Description of suitability classification for wind farm development.

\begin{tabular}{cc}
\hline Suitability Classes & Description of SI Class Range \\
\hline Not Suitable & SI $=0$ \\
Low Suitability & $0<$ SI $\leq 0.50$ \\
Moderate Suitability & $0.50<$ SI $\leq 0.75$ \\
High Suitability & SI $\leq 1$
\end{tabular}

Source: Adopted from [10]. 
(LG) to determine the spread per LG. According to [10], the priority areas are of keen interest for further examination as they represent an increased probability of identifying suitable wind farm locations in the real-world context.

Furthermore, we identified and delineated the most suitable locations for wind farm development by extracting the high suitability parcels in each priority LGA. Following the extraction, we converted the resulting raster to a polygon feature. Then the parcels with a total area of $5 \mathrm{~km}^{2}$ or more were selected as the most suitable locations for wind farm development in the study area. The choice of the parcel size was in line with the minimum acceptable land area for wind farm development $\left(5 \mathrm{~km}^{2}\right)$ given by [30]. For easy locating of these most suitable parcels, we calculated their centroid from which we created centre points and coordinates for individual parcels. We also determined the number of most suitable parcels per priority LGA under each policy scenario. Figure 5 and Figure 6 present the final suitability model and methodological flowchart of the study, respectively.

\section{Results and Discussion}

\subsection{Influence of Decision Criteria on Wind Farm Site Suitability in Nasarawa State}

Table 9 summarises the area of lands excluded due to the influence of individual decision constraints and due to their collective impact. The summary indicated significant variation in the land areas excluded because of the geographical distribution of the decision constraints features in the study area.

Decision constraint C1 (wind speed) had the most influence and accounted for the exclusion of almost half (46.25\%) of the entire study area. Another substantial area, representing $21.21 \%$ of Nasarawa State, was excluded based on
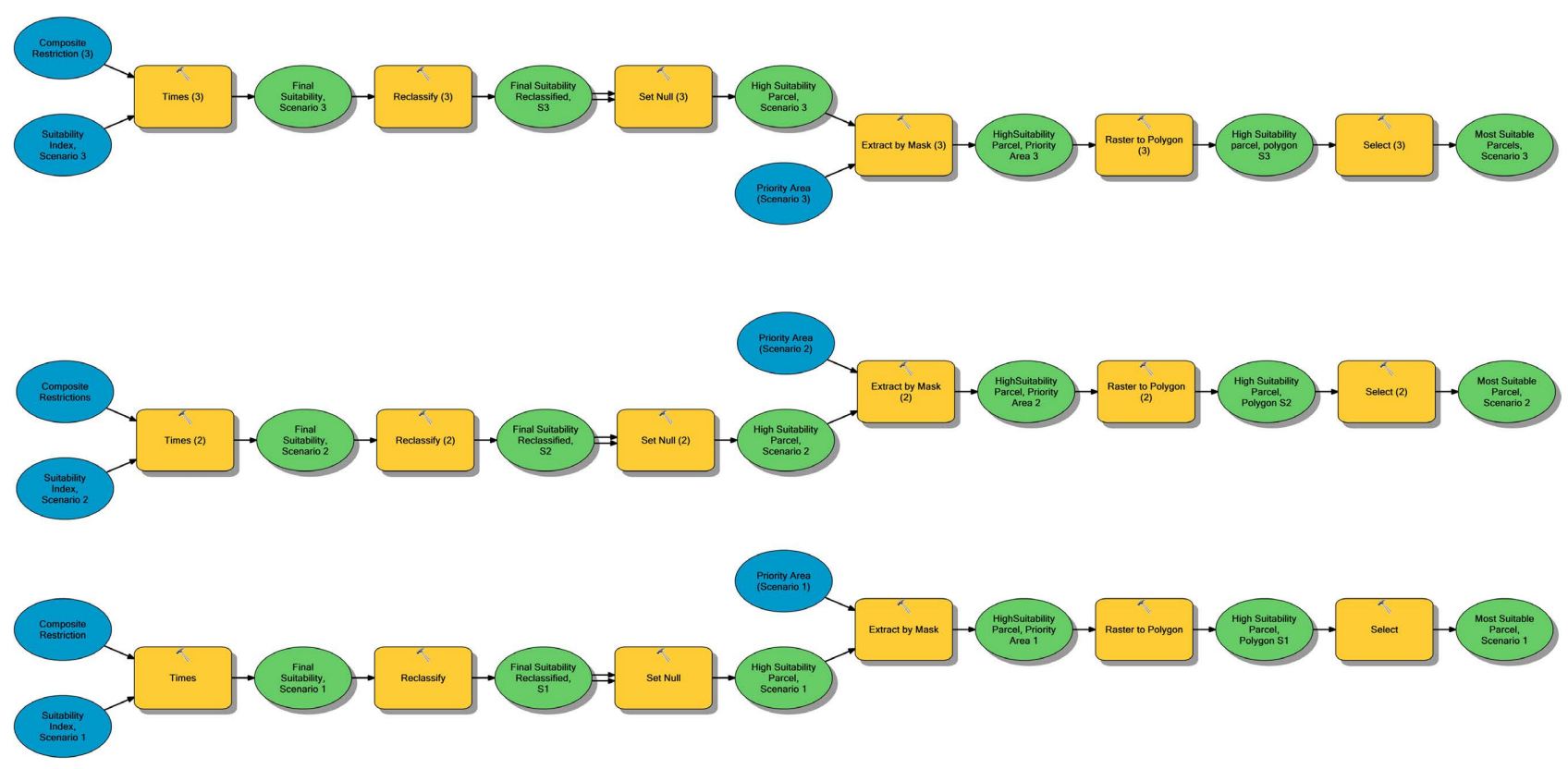

Figure 5. Final suitability model. 


\begin{tabular}{|c|c|c|c|c|c|c|c|c|}
\hline & \multicolumn{8}{|c|}{ WIND FARM SITE SUITABILITY ANALYSIS } \\
\hline & \multicolumn{6}{|c|}{ INPUT DATA (DECISION CRITERIA) } & & \\
\hline & & \multicolumn{2}{|c|}{ DECISION CONSTRAINTS } & \multicolumn{4}{|c|}{ DECISION FACTORS } & \\
\hline \multirow[t]{6}{*}{$\begin{array}{l}\text { Wind } \\
\text { Speed }\end{array}$} & $\begin{array}{l}\text { Built-up } \\
\text { Area }\end{array}$ & $\begin{array}{l}\text { Environmental } \\
\text { Protection (Forest } \\
\text { reserves, Wetlands \& } \\
\text { Waterbodies) }\end{array}$ & $\begin{array}{l}\text { Safety } \\
\text { Restrictions (Road } \\
\text { and Railway) }\end{array}$ & $\begin{array}{l}\text { Wind } \\
\text { Speed }\end{array}$ & $\begin{array}{c}\text { Slope } \\
\text { Gradient }\end{array}$ & $\begin{array}{l}\text { Proximity to } \\
\text { Transmission } \\
\text { Network }\end{array}$ & $\begin{array}{l}\text { Proximity } \\
\text { to Road } \\
\text { Network }\end{array}$ & \multirow{2}{*}{$\begin{array}{l}\text { Distance from } \\
\text { Ecologically } \\
\text { significant Areas } \\
\text { (F. Reserves, } \\
\text { Wetlands \& } \\
\text { Waterbodies) }\end{array}$} \\
\hline & & Waterbodies) & & & & & $\begin{array}{c}\text { Land } \\
\text { Use }\end{array}$ & \\
\hline & \multicolumn{3}{|c|}{$\begin{array}{l}\text { Analysis of Decision Constraints: Identification of } \\
\text { exclusion zones and compilation of composite constraint } \\
\text { layer (Boolean raster layers) using buffer and raster } \\
\text { calculator tools in Spatial Analyst Toolbox. }\end{array}$} & \multicolumn{5}{|c|}{$\begin{array}{l}\text { Standardization of Decision Factors: Standardisation of decision } \\
\text { factors by application of the fuzzy sets theory or a Likert-type } \\
\text { scale/binary scoring system where required (ArcGIS Spatial Analyst } \\
\text { toolbox). }\end{array}$} \\
\hline & & & & \multicolumn{5}{|c|}{$\begin{array}{l}\text { MCDA and Suitability Index: } \\
\text {-Combination of decision factors using the weighted linear } \\
\text { combination method and weights derived from pairwise comparisons } \\
\text { (analytic hierarchy process) } \\
\text { - Implementation of MCDA and compilation of suitability index for } \\
\text { three policy scenarios (ArcGIS Spatial Analyst toolbox). }\end{array}$} \\
\hline & \multicolumn{8}{|c|}{$\begin{array}{l}\text { Identification/delineation of Priority Areas } \\
\text { - Reclassification of final suitability index } \\
\text {-Calculation of area }\left(\mathrm{km}^{2}\right) \text { statistics for defined suitability classes within LGAs (ArcGIS Spatial Analyst toolbox) } \\
\text { - The six LGAs with the highest percentage of land classified as 'high suitability' (SI >0.75) nominated as priority areas }\end{array}$} \\
\hline & \multicolumn{8}{|c|}{$\begin{array}{l}\text { Identification/delineation of Optimal Locations } \\
\text { - Extraction of respective suitability index (ArcGIS Spatial Analyst toolbox-extraction) } \\
\text { - Conversion of raster suitability index to polygon (ArcGIS Conversion toolbox) } \\
\text { - Selection of parcels with total area of } 5 \mathrm{~km}^{2} \text { or more i.e., most suitable locations for each policy scenario (Analysis toolbox-select) }\end{array}$} \\
\hline
\end{tabular}

Figure 6. Methodological flowchart.

Table 9. Area of exclusion zones due to decision constraints' influence.

\begin{tabular}{ccc}
\hline Decision Constraint & Exclusion Zone Area $\left(\mathrm{Km}^{2}\right)$ & Percent of the Total Study Area (\%) \\
\hline Wind Restriction & $12,286.41$ & 46.25 \\
Environmental Restrictions & 5634.74 & 21.21 \\
Safety Restrictions & 1198.81 & 4.51 \\
Settlement Restriction & 689.30 & 2.60 \\
Composite Restriction & $15,347.13$ & 57.58 \\
\hline
\end{tabular}

environmental protection. Conversely, land areas excluded based on safety concerns and settlement preservation accounted for relatively small portions of the study area, representing $4.51 \%$ and $2.60 \%$, respectively. Overall, more than half (57.58\%) of the entire study area was deemed exclusion zones due to the collective influence of decision constraints. Figure 7 shows the exclusion of more lands in the southwestern region of the State than in the other parts. Nasarawa, Toto, Karu, Keffi, Kokona and Doma are the most affected LGAs. This result indicates that wind speed and environmental protection criteria are the two main constraints of wind energy farm development in the study area.

Furthermore, the outright exclusion of $57.58 \%$ of the study area from further 


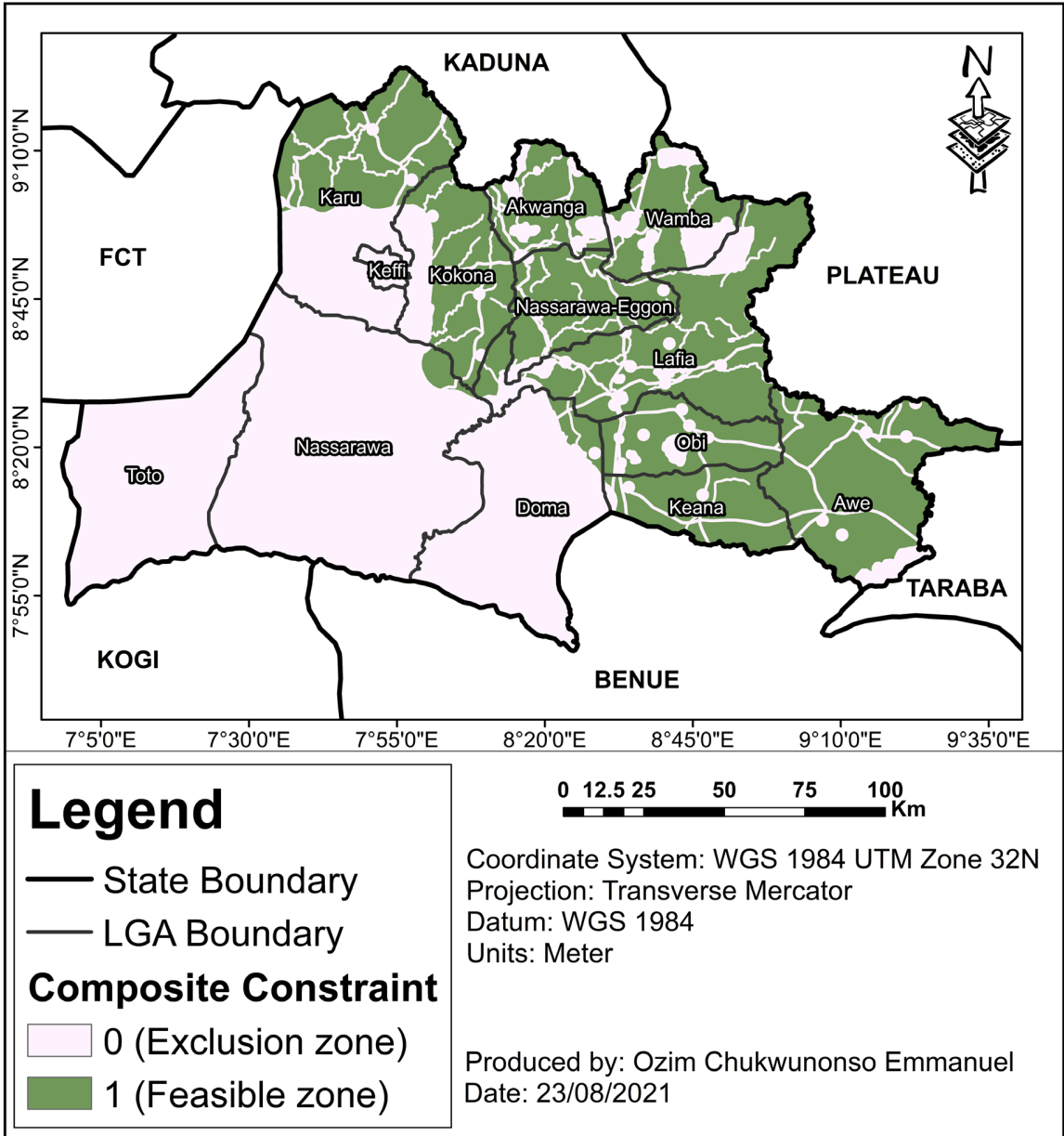

Figure 7. Composite constraint map depicting exclusion and feasible zones.

assessment indicates fewer potential development sites for wind energy farms when compared to the findings of [10] and [28] who reported a composite constrained area of $27.6 \%$ for New South Wales in Australia and 56.8\% for Lesvos Island in Greece, respectively. However, there is still an appreciable area $(42.42 \%)$ with wind farm development potential when compared to the studies of [1] who reported a constraint layer accounting for $83 \%$ of their study area in the region of Kozani, Greece; and [11] whose environmental constraint layer only, accounted for the exclusion of $62.2 \%$ of their study area in southern England.

In addition to the Boolean-based analysis result, the complementary mean fuzzy membership values of the decision factors are presented in Table 10. The mean values describe the impact of the deciding factors on the varying degrees of wind farm site suitability across the study area.

The majority of the decision factors created moderate to high suitability conditions across Nasarawa State with higher membership values than the "moderate $(\mathrm{SI}>0.50)$ and high $(\mathrm{SI}>0.75)$ suitability threshold". The result showed a mean value of 0.7518 for decision factor F5 (distance from ecologically significant areas). This value is above the high suitability threshold and thus, creating 
Table 10. Mean membership value of the decision factors.

\begin{tabular}{cc}
\hline Decision Factor & Mean Membership Value \\
\hline Wind Speed & 0.2008 \\
Slope & 0.5202 \\
Proximity to Transmission Network & 0.6156 \\
Proximity to Road & 0.5466 \\
Distance from Ecologically Significant Area & 0.7518 \\
Land cover/use & 0.6278 \\
\hline
\end{tabular}

high suitability conditions within the study area. Decision factors F2 (slope), F3 (proximity to the road), F4 (proximity to transmission network) and F6 (land cover/use) with mean values of $0.5202,0.5466,0.6156$ and 0.6278 , respectively produced "moderate suitability" conditions across most parts of the study area and thus, contributed to the availability of land areas deemed "acceptable" (0.50 $<$ SI $\leq 1$ ) for wind farm development.

On the contrary, decision factor F1 (wind speed) with a mean value of 0.2008 recorded low membership values in most parts of the study area. This result mirrors the observation with decision constraint $\mathrm{C} 1$, identified as the main limiting factor of suitable sites for wind farm development in Nasarawa State. It also corroborates the findings of [1] and [10] that also reported wind speed as the predominant limiting factor of wind farm land suitability in their studies.

\subsection{Suitability Index (SI) for the Policy Priority Scenarios}

The final suitability index result for the three-policy scenario is presented in Figures 8-10. The respective scenario maps depict varying degrees of site suitability for wind energy farms in the study area. This finding indicates that the developed decision support model is susceptible to changes in policy objectives. The composite suitability values varied between zero $\{0\}$, the not suitable locations and one $\{1\}$, the optimal locations, with SI mean values of 0.2544 for scenario $1 ; 0.3118$ for scenario 2 ; and 0.2102 for scenario 3 . Table 11 presents the total satisfactory areas for wind farm development under the respective policy scenarios.

This finding reveals that almost half of the entire study area is deemed acceptable for wind farm projects when the goal is to ensure minimal negative environmental and social impacts. Fewer land areas are available for such projects when the priority is to minimise installation costs and ensure adequate project revenue. The values in Table 11 compared well with similar studies and are considered substantial for wind farm development projects in the State under the three policy scenarios. For instance, in the study of [1], the high suitability index (SI $\geq 0.7$ ) area comprised $2.2 \%$ of their study area for economic/technical policy scenarios and $11.8 \%$ for environmental/social policy scenarios. Also, [11] found a "most suitable" area (SI > 0.7) that represented less than $0.1 \%$ of their study area. 


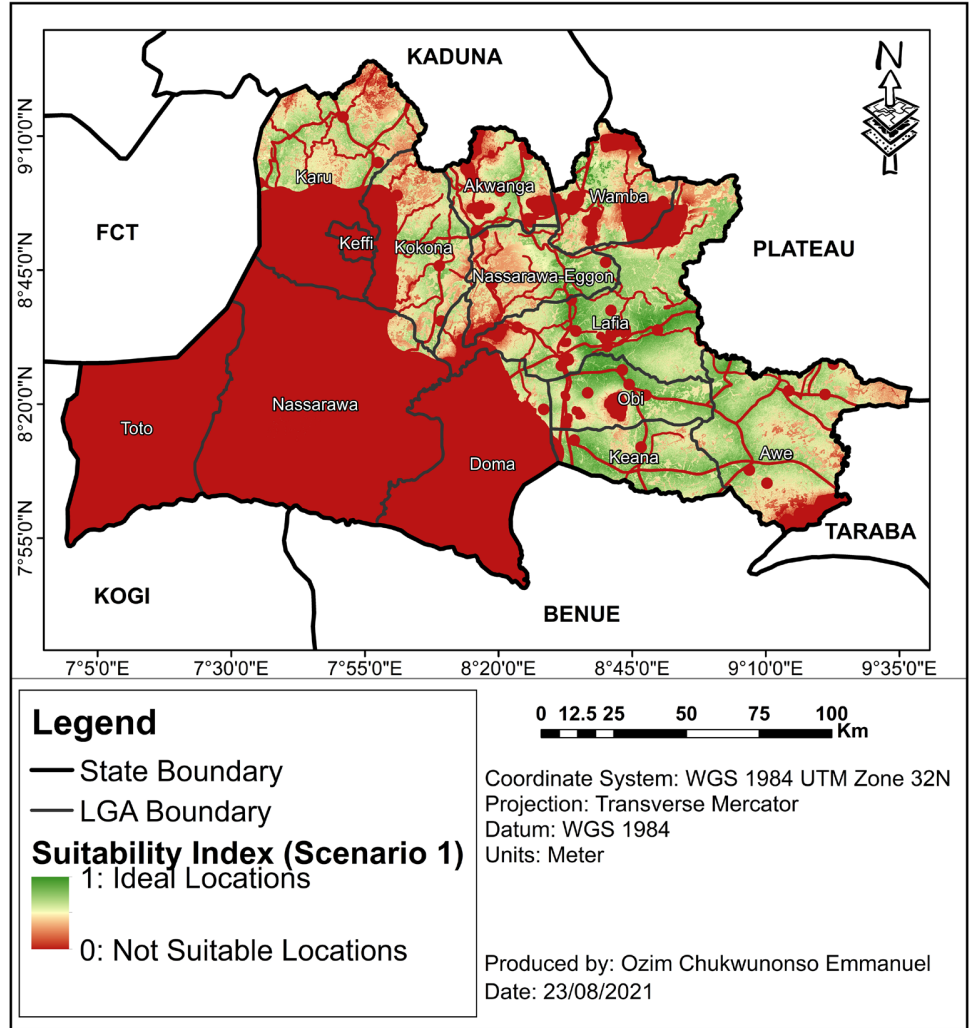

Figure 8. Suitability index (scenario 1).

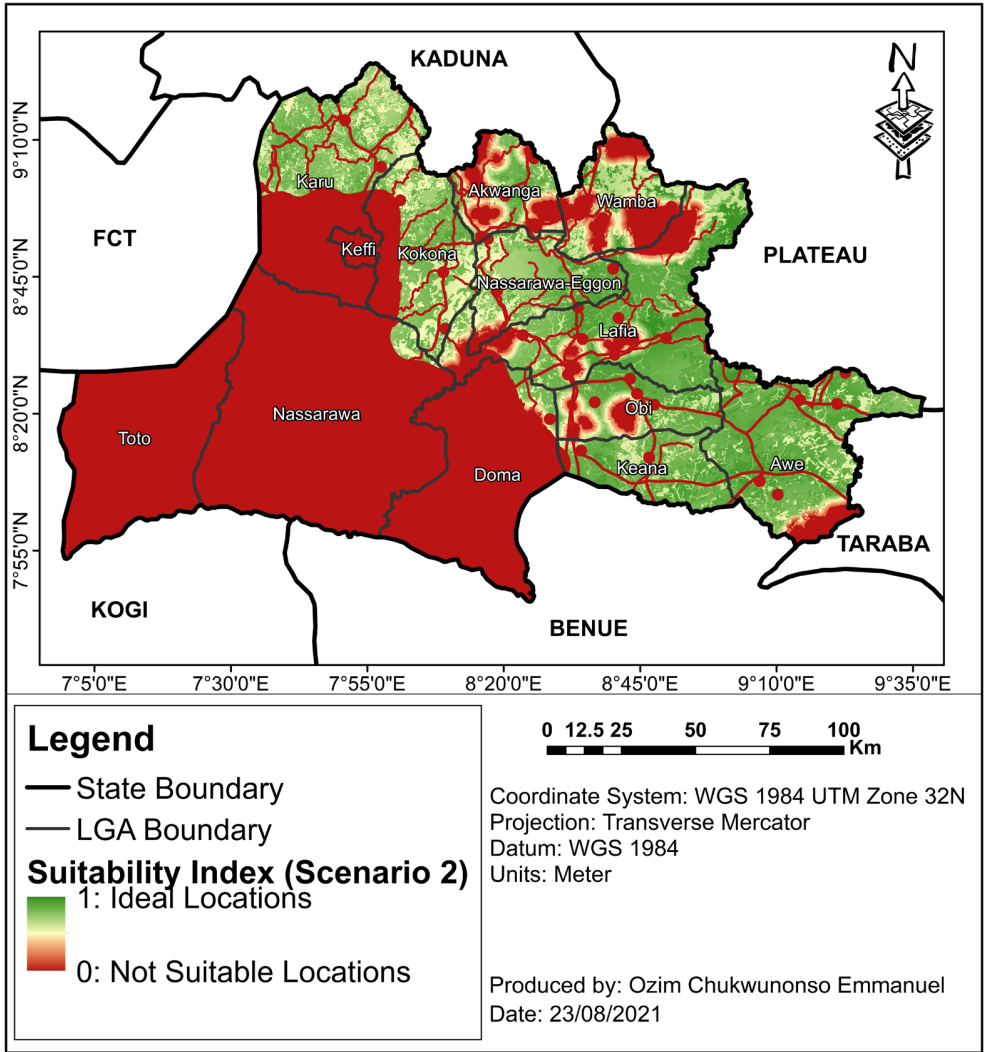

Figure 9. Suitability index (scenario 2). 


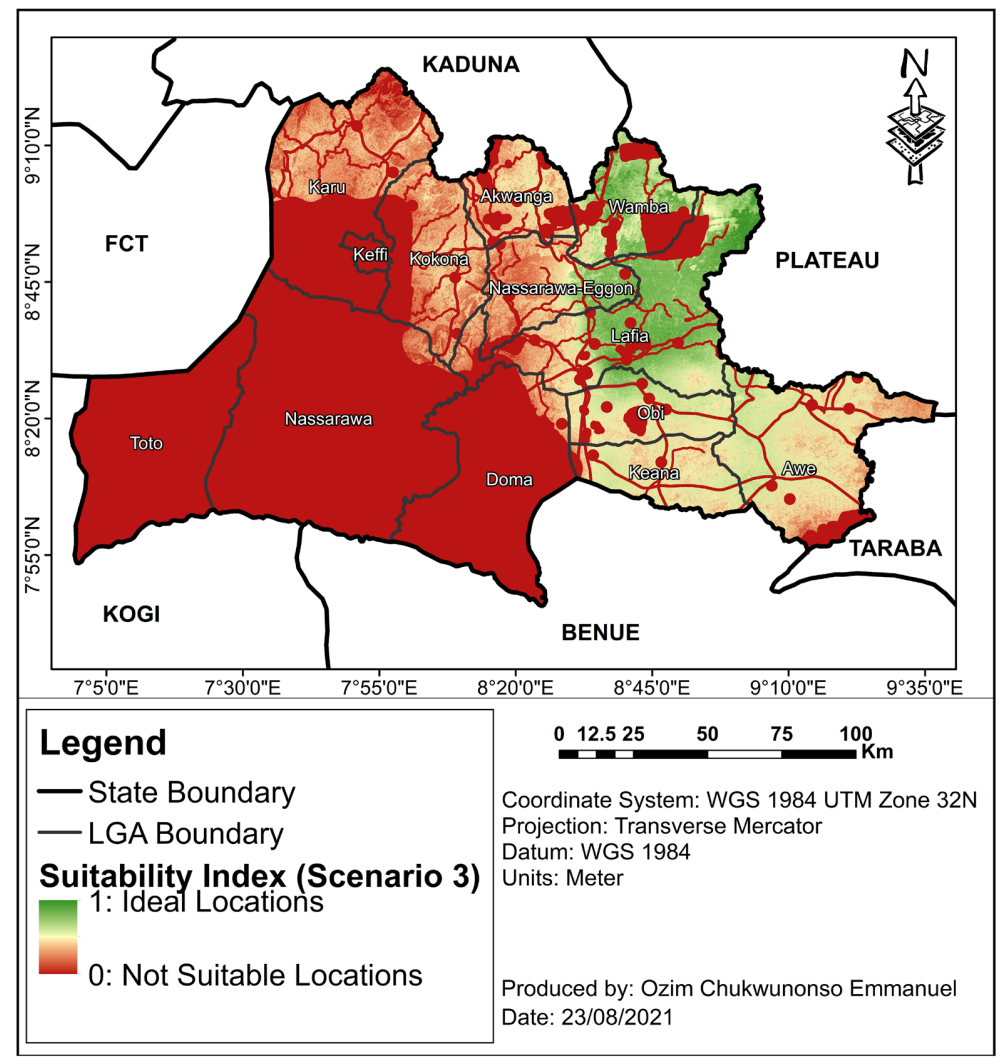

Figure 10. Suitability index (scenario 3).

Table 11. Statistics of the suitability index maps.

\begin{tabular}{cccc}
\hline Policy Scenario & $\begin{array}{c}\text { High } \\
\text { Suitability Area } \\
\left(\mathrm{km}^{2}\right)\end{array}$ & $\begin{array}{c}\text { Moderate } \\
\text { Suitability Area } \\
\left(\mathbf{k m}^{2}\right)\end{array}$ & $\begin{array}{c}\text { Total Acceptable } \\
\text { Area }\left(\mathrm{km}^{2}\right)\end{array}$ \\
\hline Equal weights (1) & $982.79(3.70 \%)$ & $7976.01(30.03 \%)$ & $8958.80(36.34 \%)$ \\
Environmental/Social Priority (2) & $6973.64(26.25 \%)$ & $3487.37(13.13 \%)$ & $10,461.01(42.44 \%)$ \\
Economic Priority (3) & $346.02(1.30 \%)$ & $4885.78(18.39 \%)$ & $5231.80(21.22 \%)$ \\
\hline
\end{tabular}

Furthermore, this study presents more viable options for wind farm development than was reported by [1]. They found only $12 \%$ of their study area in Greece to represent "satisfactory" locations (SI > 0.50). These variations in total land areas deemed "satisfactory" across the compared studies could be due to the variations in the degree of restrictions/constraints exerted by each decision criteria, particularly wind speed, in the various study areas. Additional reasons could be the differences in weights assigned to respective decision factors, the spatial resolution of the input data, the magnitude of the study area and the regularised input data cell size used in the analysis.

\subsection{Priority Areas for Wind Farm Development}

Table 12 presents the statistics of priority LGAs for the respective policy scenarios. It shows the names of the LGAs; the total administrative area of the 
Table 12. Statistics of priority areas for each policy scenario.

\begin{tabular}{|c|c|c|c|c|}
\hline $\begin{array}{c}\text { Policy } \\
\text { Scenario }\end{array}$ & LGA & $\begin{array}{l}\text { Total Land Area of } \\
\text { LG }\left(\mathrm{km}^{2}\right)\end{array}$ & $\begin{array}{l}\text { Total Area of High } \\
\text { Suitability }\left(\mathrm{km}^{2}\right)\end{array}$ & $\begin{array}{c}\text { Percent of High } \\
\text { Suitability (\%) }\end{array}$ \\
\hline \multirow[t]{6}{*}{1} & Obi & 1039.73 & 170.07 & 16.36 \\
\hline & Keana & 1079.15 & 153.25 & 14.20 \\
\hline & Lafia & 2950.29 & 310.28 & 10.52 \\
\hline & Nassarawa-Eggon & 1237.23 & 71.72 & 5.80 \\
\hline & Awe & 2525.52 & 134.66 & 5.33 \\
\hline & Wamba & 1212.87 & 54.13 & 4.46 \\
\hline \multirow[t]{6}{*}{2} & Awe & 2525.52 & 1682.41 & 66.62 \\
\hline & Keana & 1079.15 & 706.68 & 65.49 \\
\hline & Lafia & 2950.29 & 1519.92 & 51.52 \\
\hline & Nassarawa-Eggon & 1237.23 & 554.05 & 44.78 \\
\hline & Obi & 1039.73 & 454.38 & 43.70 \\
\hline & Kokona & 1699.16 & 649.20 & 38.21 \\
\hline \multirow[t]{4}{*}{3} & Lafia & 2950.29 & 253.31 & 8.59 \\
\hline & Wamba & 1212.87 & 65.56 & 5.41 \\
\hline & Nassarawa-Eggon & 1237.23 & 20.64 & 1.67 \\
\hline & Obi & 1039.73 & 4.47 & 0.43 \\
\hline
\end{tabular}

LGAs; the area and percentage of high suitability (SI > 0.75) parcel within the respective LGAs.

Six LGA comprised the priority areas under each of the policy scenarios 1 and 2. The LGAs include Obi, Keana, Lafia, Nasarawa-Eggon and Awe. Wamba and Kokona are the sixth LGAs in scenarios 1 and 2, respectively. Although only four LGAs comprised the priority areas under policy scenario 3, the LGAs are similar to those of scenarios 1 and 2. Overall, 7 of the 13 LGAs in the State comprised the priority areas of focus in the quest for the most suitable locations for wind farm projects across the study area.

High suitability locations suggest high prospects of finding optimal wind farm locations in the real-world context. Obi LGA had $16.36 \%$ of its area under high suitability conditions and accounted for the most spread $\left(170.07 \mathrm{~km}^{2}\right)$ of high suitability area in scenario 1 . Other LGAs with relatively high suitability areas were Kean (14.20\%) and Lafia (10.52\%). Wamba had only $4.46 \%$ of its area under high suitability conditions making it the LGA with the smallest spread of high suitability areas. Therefore, there is a low likelihood of finding optimal wind farm locations in Wamba than Obi, Keana and Lafia. All the six priority LGAs under policy scenario 2 showed high prospects for identifying optimal wind farm locations. More than $30 \%$ of their administrative areas were of high suitability conditions. Awe (66.625\%) and Keana (65.49\%) recorded the most spread, whereas Obi (38.21\%) and Kokona (38.21\%) accounted for the least. The 
four priority LGAs under the economic policy scenario presented little or no potential for finding ideal wind farm locations. Only $8.59 \%$ of Lafia's administrative area was of high suitability conditions, followed by $5.41 \%$ of Wamba, $1.67 \%$ of Nasarawa-Eggon and $0.43 \%$ of Obi.

The spatial locations of the priority LGAs identified under each of the three policy scenarios were delineated by Figures 11-13. A visual assessment of the maps revealed slight variations in the geographical locations of the priority areas. These variations mirrored the final suitability index maps and suggest that the developed decision support model is susceptible to changes in policy objectives. Furthermore, it is visually ascertainable that only three out of the seven priority LGAs maintained consistency with changes in policy objectives. These include: Lafia, Obi and Nasarawa-Eggon. According to [13], one of the various sources of uncertainty in Multi-Criteria Decision Analysis remains the allotting of weights to individual decision factors. Therefore, they argued that any attempt to identify the priority areas, locations whose suitability are susceptible to slight alterations in the relative importance weighting of criteria do not present the best possible option. Only those areas that maintained high suitability conditions across all investigated policy scenarios are in the best position for further analysis. Consequently, it is imperative to deem Lafia, Obi and Nasarawa-Eggon LGAs the topmost options among the priority locations for wind farm development in Nasarawa State.

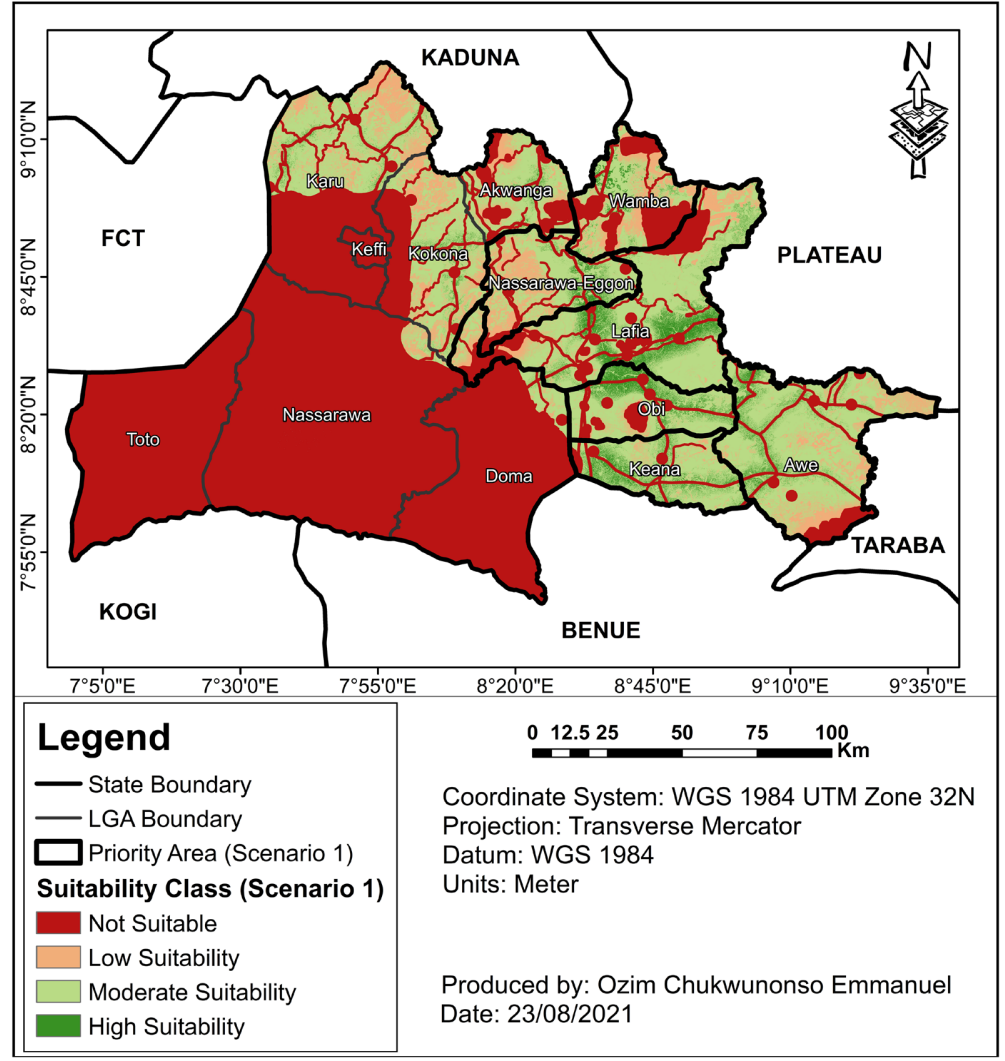

Figure 11. Priority area (policy scenario1-equal weights). 


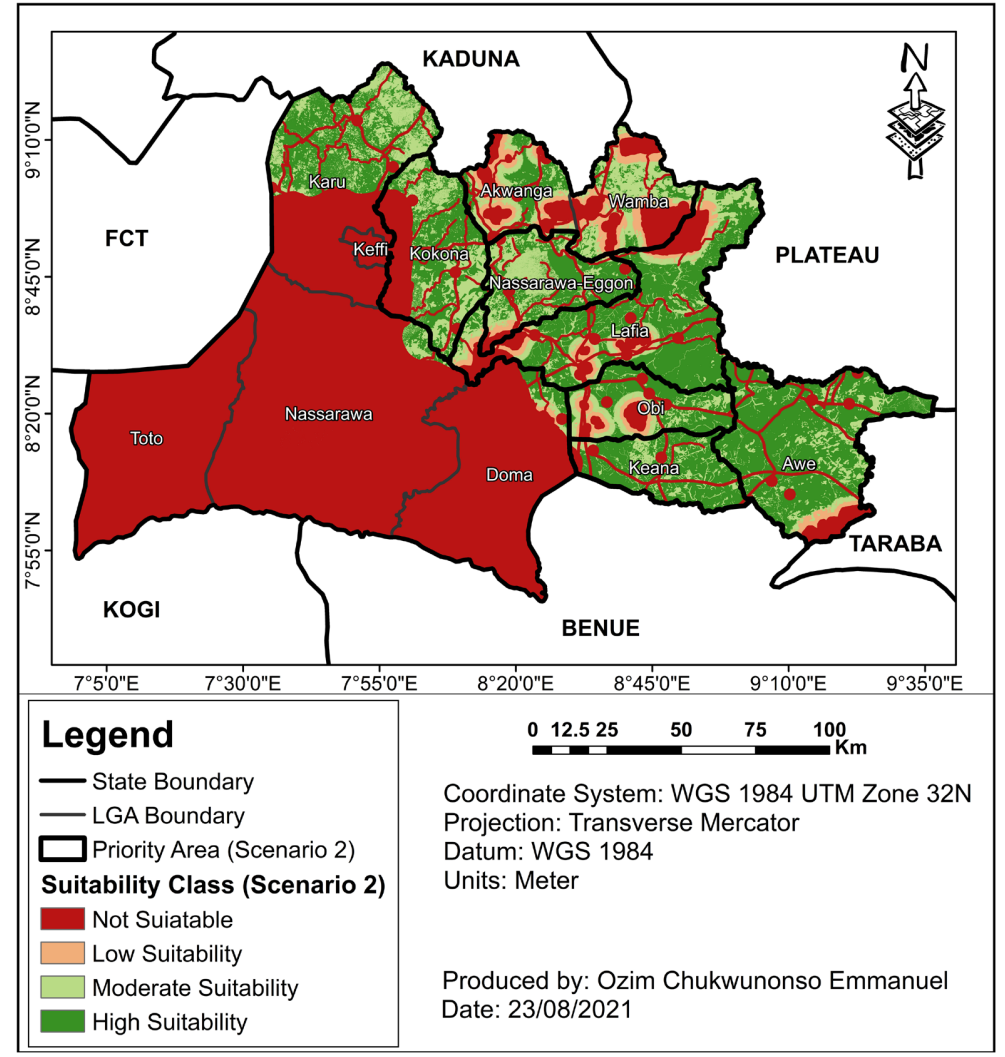

Figure 12. Priority area (policy scenario 2-environmental social priority).

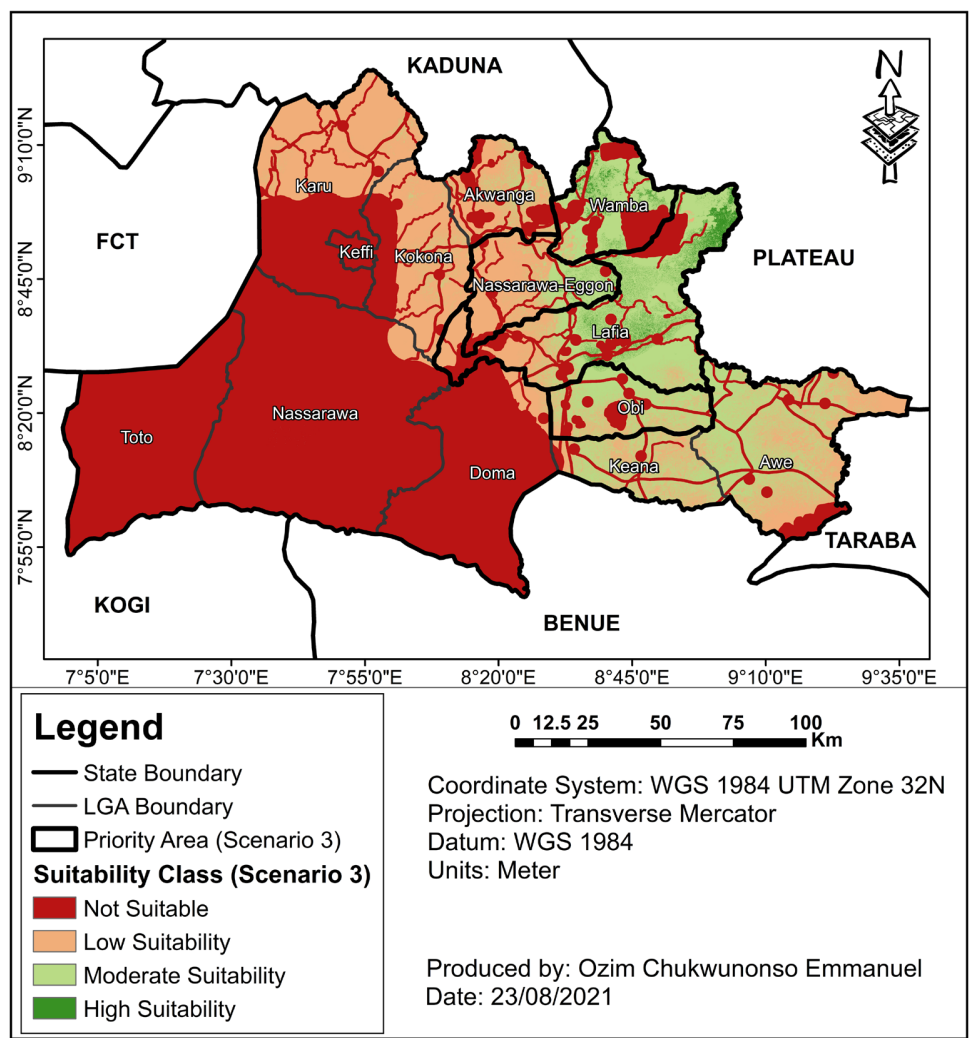

Figure 13. Priority area (policy scenario 3-economic priority). 


\subsection{Most Suitable Area for Wind Farm Development}

Figures 14-16 present maps of the "most suitable" locations for wind farm development in Nasarawa State. The maps depict high suitability parcels that are equal to or greater than $5 \mathrm{~km}^{2}$. Under policy scenario 1 (Equal weights), we found a total of 13 most suitable parcels of land. Six are in Lafia, 3 in Obi, 2 in Keana and 1 in Awe and Nasarawa-Eggon. No part of Wambe LGA satisfied the conditions for being selected among the most suitable parcels. Also, in scenario

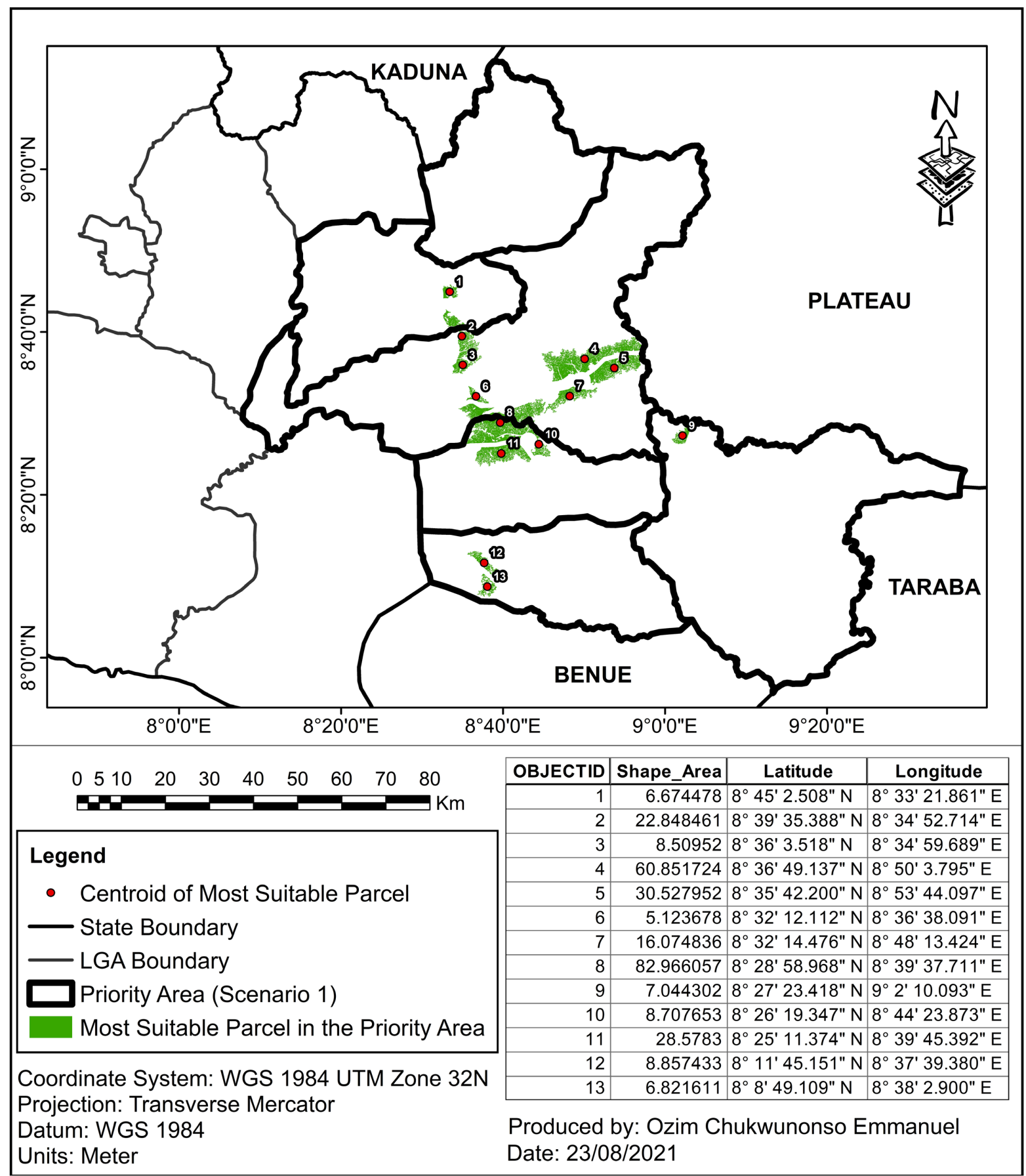

Figure 14. Locations of most suitable parcels in priority area 1. 


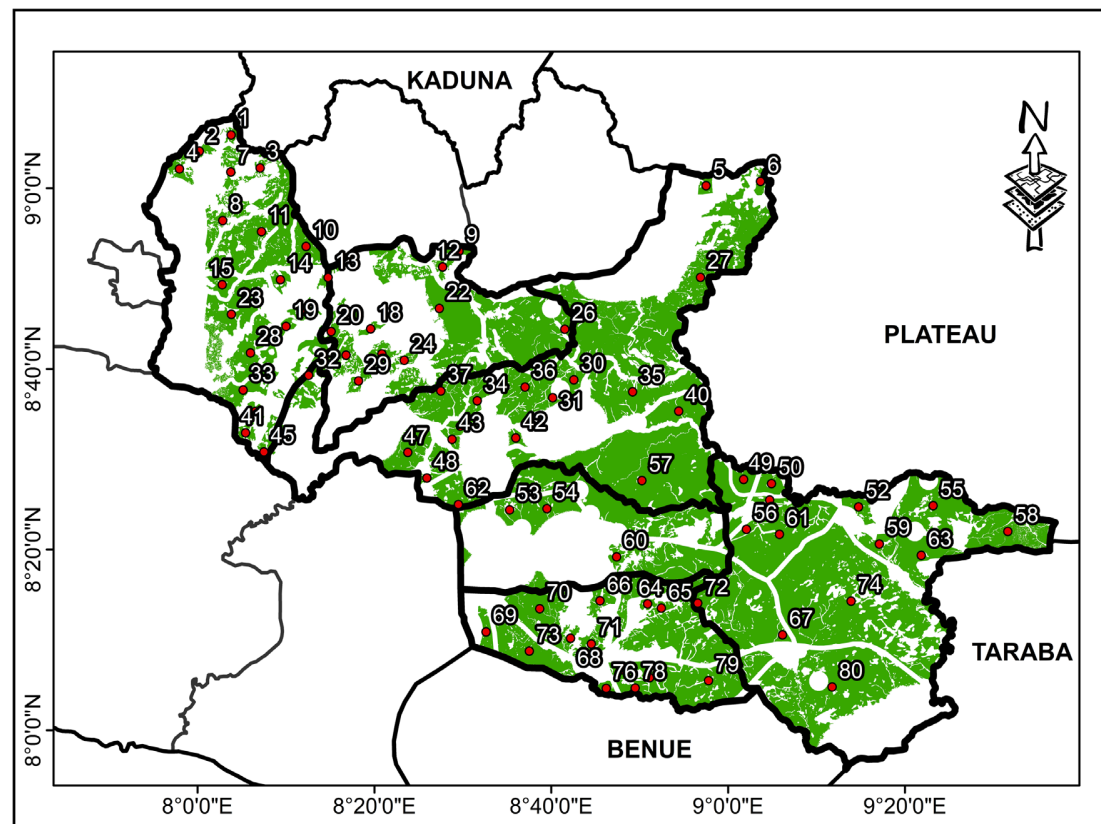

$\begin{array}{lllllllll}0 & 510 & 20 & 30 & 40 & 50 & 60 & 70 & 80\end{array}$

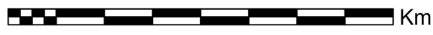

\section{Legend}

- Centroid of Most Suitable Parcel

\section{- State Boundary}

\section{— LGA Boundary}

$\square$ Priority Area (Scenario 2)

Most Suitable Parcel in the Priority Area

Coordinate System: WGS 1984 UTM Zone 32N

Projection: Transverse Mercator

Datum: WGS 1984

Units: Meter

Produced by: Ozim Chukwunonso Emmanuel

Date: $23 / 08 / 2021$ \begin{tabular}{|l|l|c|c|}
\hline OBJECTID & Shape_Area & Latitude & Longitude \\
\hline
\end{tabular} \begin{tabular}{|r|r|c|c|}
\hline 1 & 5.743052 & $9^{\circ} 5^{\prime} 57.311^{\prime \prime} \mathrm{N}$ & $8^{\circ} 3^{\prime} 37.589^{\prime \prime} \mathrm{E}$ \\
\hline 2 & 8.568836 & $9^{\circ} 4^{\prime} 8.538^{\prime \prime} \mathrm{N}$ & $8^{\circ} 0^{\prime} 1.395^{\prime \prime} \mathrm{E}$ \\
\hline
\end{tabular} \begin{tabular}{lll|l|l|l|l}
\hline & 8.568836 & $9^{\circ} 4^{\prime} 8.538^{\prime \prime} \mathrm{N}$ & $8^{\circ} 0^{\prime} 1.395^{\prime \prime} \mathrm{E}$ \\
\hline
\end{tabular} \begin{tabular}{l|r|r|r|}
3 & 8.991268 & $9^{\circ}$ & 2 \\
\hline
\end{tabular} \begin{tabular}{|r|r|r|r|}
\hline & 15.997342 & $9^{\circ}$ & 2 \\
\hline
\end{tabular} $58.7942169^{\circ} 00^{\prime} 24.249 " \mathrm{~N} \quad 8^{\circ} 57^{\prime} 30.362 " \mathrm{E}$ $8.9894999^{\circ} 00^{\prime} 53.610^{\prime \prime} \mathrm{N} \quad 9^{\circ} 3^{\prime} 40.649 " \mathrm{E}$

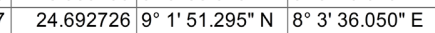
$8 \quad 28.0257938^{\circ} 56^{\prime} 28.120^{\prime \prime} \mathrm{N} 8^{\circ} 2^{\prime} 41.467^{\prime \prime} \mathrm{E}$ 9 $8.6871878^{\circ} 53^{\prime} 8.070^{\prime \prime} \mathrm{N} \quad 8^{\circ} 29^{\prime} 29.867 " \mathrm{E}$ $10 \quad 31.9989698^{\circ} 53^{\prime} 38.015^{\prime \prime} \mathrm{N} 8^{\circ} 12^{\prime} 9.3322^{\prime \prime} \mathrm{E}$ $11 \quad 178.5482678^{\circ} 55^{\prime} 15.146^{\prime \prime} \mathrm{N} 8^{\circ} 7^{\prime} 5.691^{\prime \prime} \mathrm{E}$

$12 \quad 7.2688098^{\circ} 51^{\prime} 22.695^{\prime \prime} \mathrm{N} 8^{\circ} 27^{\prime} 38.207^{\prime \prime} \mathrm{E}$ $13 \quad 7.5009368^{\circ} 50^{\prime} 11.753^{\prime \prime} \mathrm{N} 8^{\circ} 14^{\prime} 39.298^{\prime \prime} \mathrm{E}$ $14 \quad 9.8618578^{\circ} 49^{\prime} 56.216^{\prime \prime} \mathrm{N} 8^{\circ} 9^{\prime} 15.028^{\prime \prime} \mathrm{E}$

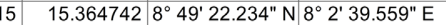
$16 \quad 12.1374598^{\circ} 46^{\prime} 29.081^{\prime \prime} \mathrm{N} 8^{\circ} 11^{\prime} 54.872 " \mathrm{E}$ $17 \quad 6.8403368^{\circ} 46^{\prime} 26.691 " \mathrm{~N} 8^{\circ} 17^{\prime} 2.669^{\prime \prime} \mathrm{E}$ $18 \quad 5.8690828^{\circ} 44^{\prime} 30.828^{\prime \prime} \mathrm{N} 8^{\circ} 19^{\prime} 29.383^{\prime \prime} \mathrm{E}$ $197.8195038^{\circ} 44^{\prime} 46.396^{\prime \prime} \mathrm{N} 8^{\circ} 9^{\prime} 54.185^{\prime \prime} \mathrm{E}$ $20 \quad 11.7218688^{\circ} 44^{\prime} 13.153^{\prime \prime} \mathrm{N} 8^{\circ} 15^{\prime} 1.036^{\prime \prime} \mathrm{E}$ $21 \quad 15.058858^{\circ} 41^{\prime} 45.105^{\prime \prime} \mathrm{N} 8^{\circ} 20^{\prime} 46.531^{\prime \prime} \mathrm{E}$ 22 165.445063 $8^{\circ} 46^{\prime} 47.602 " \mathrm{~N} 8^{\circ} 27^{\prime} 16.600^{\prime \prime} \mathrm{E}$ $23 \quad 88.4796458^{\circ} 46^{\prime} 5.385^{\prime \prime} \mathrm{N} \quad 8^{\circ} 3^{\prime} 42.687^{\prime \prime} \mathrm{E}$

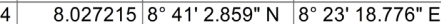
$25 \quad 25.7166838^{\circ} 41^{\prime} 36.405^{\prime \prime} \mathrm{N} 8^{\circ} 16^{\prime} 42.325^{\prime \prime} \mathrm{E}$ $26 \quad 367.5955758^{\circ} 44^{\prime} 29.8866^{\prime \prime} \mathrm{N} 8^{\circ} 41^{\prime} 29.910^{\prime \prime} \mathrm{E}$ $27291.6758278^{\circ} 50^{\prime} 15.477^{\prime \prime} \mathrm{N} 8^{\circ} 56^{\prime} 52.725^{\prime \prime} \mathrm{E}$ $61.664898^{\circ} 41^{\prime} 49.859^{\prime \prime} \mathrm{N} 8^{\circ} 5^{\prime} 52.269^{\prime \prime} \mathrm{E}$ $9.6212228^{\circ} 38^{\prime} 45.458^{\prime \prime} \mathrm{N} 8^{\circ} 18^{\prime} 7.648^{\prime \prime} \mathrm{E}$ $13.449818^{\circ} 38^{\prime} 54.744^{\prime \prime} \mathrm{N} 8^{\circ} 42^{\prime} 31.575^{\prime \prime} \mathrm{E}$ $6.0435488^{\circ} 36^{\prime} 55.363^{\prime \prime} \mathrm{N} 8^{\circ} 40^{\prime} 8.026^{\prime \prime} \mathrm{E}$ $56.1761328^{\circ} 39^{\prime} 21.921 " \mathrm{~N} 8^{\circ} 12^{\prime} 28.791 " \mathrm{E}$ $36.2146398^{\circ} 37^{\prime} 42.884 " \mathrm{~N} 8^{\circ} 5^{\prime} 3.661^{\prime \prime} \mathrm{E}$ $13.0487968^{\circ} 36^{\prime} 35.069^{\prime \prime} \mathrm{N} 8^{\circ} 31^{\prime} 35.034^{\prime \prime} \mathrm{E}$ $117.2508798^{\circ} 37^{\prime} 35.283^{\prime \prime} \mathrm{N} 8^{\circ} 49^{\prime} 11.233^{\prime \prime} \mathrm{E}$

$107.33188^{\circ} 38^{\prime} 6.609^{\prime \prime} \mathrm{N} \quad 8^{\circ} 37^{\prime} 0.233^{\prime \prime} \mathrm{E}$ $132.9437478^{\circ} 37^{\prime} 39.481 " \mathrm{~N} 8^{\circ} 27^{\prime} 27.259^{\prime \prime} \mathrm{E}$ 7.921097 $8^{\circ} 35^{\prime} 20.404 " \mathrm{~N} 8^{\circ} 6^{\prime} 25.651 " \mathrm{E}$ $39 \quad 12.0219738^{\circ} 33^{\prime} 46.100^{\prime \prime} \mathrm{N} 8^{\circ} 29^{\prime} 40.028^{\prime \prime} \mathrm{E}$ $40 \quad 53.3776718^{\circ} 35^{\prime} 26.157 " N 8^{\circ} 54^{\prime} 24.989^{\prime \prime} \mathrm{E}$ $8.7787218^{\circ} 32^{\prime} 58.545^{\prime \prime} \mathrm{N} 8^{\circ} 5^{\prime} 21.0311^{\prime \prime} \mathrm{E}$ $7.3813218^{\circ} 32^{\prime} 27.601 " \mathrm{~N} 8^{\circ} 35^{\prime} 57.174^{\prime \prime} \mathrm{E}$ $43 \quad 6.5157898^{\circ} 32^{\prime} 18.427^{\prime \prime} \mathrm{N} 8^{\circ} 28^{\prime} 44.1966^{\prime \prime} \mathrm{E}$ $15.0000838^{\circ} 322^{\prime} 55.393 " \mathrm{~N} 8^{\circ} 8^{\prime} 40.348^{\prime \prime} \mathrm{E}$ $5.2994258^{\circ} 30^{\prime} 52.813^{\prime \prime} \mathrm{N} 8^{\circ} 7^{\prime} 25.451^{\prime \prime} \mathrm{E}$ 21.764132 $8^{\circ} 30^{\prime} 3.259^{\prime \prime} \mathrm{N} \quad 8^{\circ} 27^{\prime} 38.669^{\prime \prime} \mathrm{E}$ $757.0446098^{\circ} 30^{\prime} 51.315^{\prime \prime} \mathrm{N} 8^{\circ} 23^{\prime} 43.852^{\prime \prime} \mathrm{E}$ $5.779548^{\circ} 28^{\prime} 0.462^{\prime \prime} \mathrm{N} 8^{\circ} 25^{\prime} 53.301 " \mathrm{E}$ $20.0743048^{\circ} 27^{\prime} 52.983 " \mathrm{~N} 9^{\circ} 11^{\prime} 45.780$ " E $21.8941688^{\circ} 27^{\prime} 24.649^{\prime \prime} \mathrm{N} 9^{\circ} 4^{\prime} 55.574^{\prime \prime} \mathrm{E}$ $8.2942288^{\circ} 25^{\prime} 35.755^{\prime \prime} \mathrm{N} 9^{\circ} 4^{\prime} 43.102^{\prime \prime} \mathrm{E}$ $20.001148^{\circ} 24^{\prime} 49.970^{\prime \prime} \mathrm{N} 9^{\circ} 14^{\prime} 46.9566^{\prime \prime} \mathrm{E}$ $21.8097488^{\circ} 24^{\prime} 30.137^{\prime \prime} \mathrm{N} 8^{\circ} 35^{\prime} 15.835^{\prime \prime} \mathrm{E}$ $53.4201898^{\circ} 24^{\prime} 38.275^{\prime \prime} \mathrm{N} 8^{\circ} 39^{\prime} 29.202 " \mathrm{E}$ $112.9301058^{\circ} 24^{\prime} 58.015^{\prime \prime} \mathrm{N} 9^{\circ} 23^{\prime} 13.079^{\prime \prime} \mathrm{E}$ $7.2273248^{\circ} 22^{\prime} 21.708^{\prime \prime} \mathrm{N} 9^{\circ} 22^{\prime} 5.357 " \mathrm{E}$ $624.8437378^{\circ} 27^{\prime} 45.972 " \mathrm{~N} 8^{\circ} 50^{\prime} 14.928^{\prime \prime} \mathrm{E}$ $113.9904028^{\circ} 22^{\prime} 6.041^{\prime \prime} \mathrm{N} 9^{\circ} 311^{\prime} 41.1499^{\prime \prime} \mathrm{E}$ $23.5340638^{\circ} 20^{\prime} 43.697^{\prime \prime} \mathrm{N} 9^{\circ} 17^{\prime} 7.876^{\prime \prime} \mathrm{E}$ $60 \quad 10.2758698^{\circ} 19^{\prime} 18.399^{\prime \prime} \mathrm{N} 8^{\circ} 47^{\prime} 22.943 " \mathrm{E}$ $61171.8530558^{\circ} 21^{\prime} 48.108^{\prime \prime} \mathrm{N} 9^{\circ} 5^{\prime} 49.159^{\prime \prime} \mathrm{E}$ $62 \quad 59.5590798^{\circ} 25^{\prime} 4.609 " \mathrm{~N} \quad 8^{\circ} 29^{\prime} 27.869^{\prime \prime} \mathrm{E}$ $70.3459598^{\circ} 19^{\prime} 27.796 " \mathrm{~N} 9^{\circ} 21^{\prime} 52.204 " \mathrm{E}$ \begin{tabular}{ll|l}
5.558742 & $8^{\circ} 14^{\prime} 5.588^{\prime \prime} \mathrm{N}$ & $8^{\circ} 50^{\prime} 54.093^{\prime \prime} \mathrm{E}$ \\
\hline
\end{tabular} $58.1548328^{\circ} 13^{\prime} 37.706^{\prime \prime} \mathrm{N} 8^{\circ} 52^{\prime} 27.164^{\prime \prime} \mathrm{E}$ $16.8610328^{\circ} 14^{\prime} 26.218^{\prime \prime} \mathrm{N} 8^{\circ} 45^{\prime} 30.405^{\prime \prime} \mathrm{E}$ $6.7138858^{\circ} 10^{\prime} 40.264 " \mathrm{~N} 9^{\circ} 66^{\prime} 9.740 " \mathrm{E}$

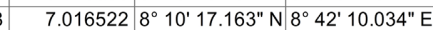
\begin{tabular}{l|r|r|}
69 & 17.338298 & $8^{\circ} 10^{\prime} 59.366 " \mathrm{~N} 8^{\circ} 32^{\prime} 36.288^{\prime \prime} \mathrm{E}$
\end{tabular} $70 \quad 110.7190158^{\circ} 13^{\prime} 33.477^{\prime \prime} \mathrm{N} 8^{\circ} 38^{\prime} 40.670^{\prime \prime} \mathrm{E}$ $7125.6384428^{\circ} 9^{\prime} 39.491 " \mathrm{~N} \quad 8^{\circ} 44^{\prime} 31.689^{\prime \prime} \mathrm{E}$ $72506.5744258^{\circ} 14^{\prime} 10.802^{\prime \prime} \mathrm{N} 8^{\circ} 56^{\prime} 34.622^{\prime \prime} \mathrm{E}$ \begin{tabular}{l|r|r|r|}
73 & 86.449124 & $8^{\circ} 8^{\prime} 51.727^{\prime \prime} \mathrm{N}$ & $8^{\circ} 37^{\prime} 31.048^{\prime \prime} \mathrm{E}$
\end{tabular} $74500.3032598^{\circ} 14^{\prime} 24.031 " \mathrm{~N} 9^{\circ} 13^{\prime} 55.586^{\prime \prime} \mathrm{E}$

$7513.7596618^{\circ} 6^{\prime} 47.698^{\prime \prime} \mathrm{N} \quad 8^{\circ} 47^{\prime} 56.756 " \mathrm{E}$ $7.9692818^{\circ} 4^{\prime} 44.037^{\prime \prime} \mathrm{N} \quad 8^{\circ} 46^{\prime} 12.771^{\prime \prime} \mathrm{E}$ \begin{tabular}{llll}
17.446908 & $8^{\circ} 5^{\prime} 55.431 " \mathrm{~N}$ & $8^{\circ} 51^{\prime} 7.189^{\prime \prime} \mathrm{E}$ \\
\hline
\end{tabular} \begin{tabular}{r|r|r|}
16.662965 & $8^{\circ} 4$ \\
\hline
\end{tabular}

$143.5633728^{\circ} 5^{\prime} 36.627^{\prime \prime} \mathrm{N} \quad 8^{\circ} 57^{\prime} 47.202^{\prime \prime} \mathrm{E}$ $80298.7295728^{\circ} 4^{\prime} 54.139 " \mathrm{~N} \quad 9^{\circ} 11^{\prime} 47.014 " \mathrm{E}$

Figure 15. Locations of most suitable parcels in priority area 2. 


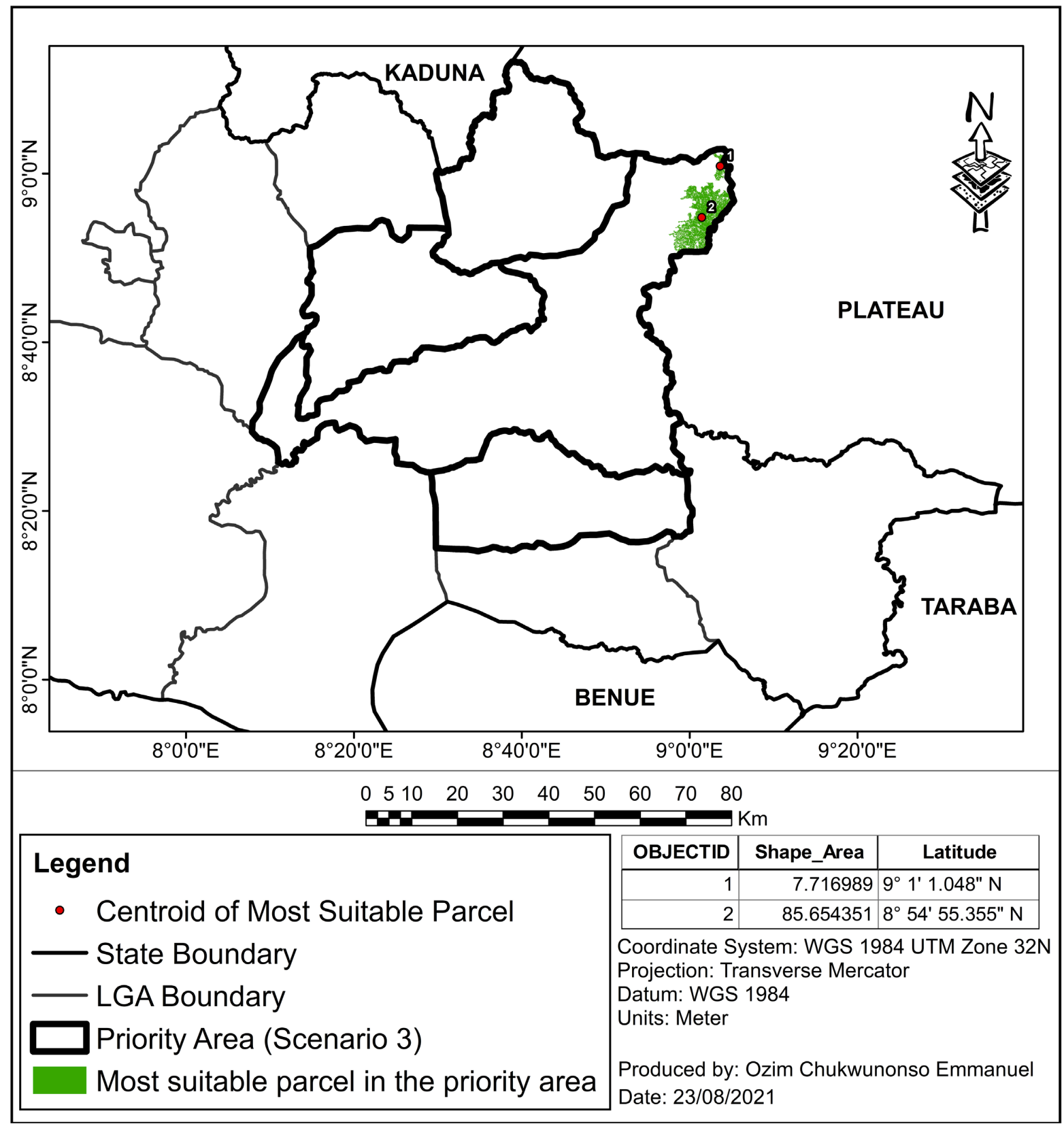

Figure 16. Locations of most suitable parcels in priority area 3.

2, we found a total of 80 parcels of land that met the most suitable conditions. Out of these parcels, 20 had their centroid located in Kokona, 19 in Lafia, 14 in Awe and 13 in Keana. The rest 14 parcels of land had their centroid located in Nasarawa-Eggon (11) and Obi (3) LGAs. In scenario 3, we found only two parcels of land considered the most suitable locations for wind farm development. They are both located in Lafia. The most suitable parcels of land had almost identical geographical positions but the numbers varied across the priority areas. This finding indicates relatively low sensitivity of the most suitable land locations to changes in policy objectives. It is also similar to the decision support tool developed by [10] for New South Wales in Australia. 
This finding implies that Lafia had the most (27) locations deemed the most suitable areas across the three policy scenarios. Hence, it presents the best option for wind farm development in the State. Also, where environmental protection is not of paramount concern, Kokona LGA shows promising prospects with the 20 most suitable locations under policy scenario 2. Other LGAs that shows wind farm development potentials under scenario 2 are Awe, Keana and Nasarawa-Eggon. Obi LGA showed an unencouraging prospect under scenario 2. This poor prospect is attributable to the substantial number of forest reserves in the LGA.

\section{Conclusions}

This study developed decision support models to identify potential wind farm locations in Nasarawa State, Nigeria. Wind speed created severe limitations to the quest for sustainable wind farm locations in the State. Despite the barrier imposed by wind speed, substantial parts of the State still show great development potentials for wind energy farms, given that $36.34 \%, 42.44 \%$ and $21.22 \%$ of the entire State satisfied the fundamental conditions under the equal weights, environmental/social and the economic policy scenarios, respectively. Lafia, $\mathrm{Na}$ sarawa-Eggon, and Obi LGAs are consistent priority areas across the three investigated policy scenarios and are thus, regarded as areas of peculiar interest for further assessment. The study recommends that the "most suitable" locations in Lafia, Nasarawa-Eggon, and Obi LGAs receive first consideration for wind energy farm development in the State. The results from this study could be resourceful to the State and the local governments in performing land management and risk assessment.

The variations in the comprehensiveness of input datasets may affect the accuracy of GIS-based WLC results. Hence, it becomes imperative to note that; (1) data on critical habitat used in this study did not include the locations of some critical habitats (zoo, game reserves and parks). Disclosing such areas would expose the habitat to a significant threat. Also, the input data on wind speed was at $50 \mathrm{~m}$ height above ground level. Data at higher elevations may result in higher potential areas for wind energy farms in the study area. Furthermore, the specific nature of wind turbines as their: sizes, and heights, were not considered. Any proposal for wind farm projects in the State would require a more specific analysis tailored to the features of the proposed turbines.

\section{Conflicts of Interest}

The authors declare no conflicts of interest regarding the publication of this paper.

\section{References}

[1] Latinopoulos, D. and Kechagia, K. (2015) A GIS-Based Multi-Criteria Evaluation for Wind Farm Site Selection. A Regional Scale Application in Greece. Renewable Energy, 78, 550-560. https://doi.org/10.1016/j.renene.2015.01.041

[2] Wiser, R., Yang, Z., Hand, M., Hohmeyer, O., Infield, D., Jensen, P.H., Nikolaev, V., 
O'Malley, M., Sinden, G. and Zervos, A. (2011) Wind Energy. In: Edenhofer, O., Pichs-Madruga, R., Sokona, Y., Seyboth, K., Matschoss, P., Kadner, S., Zwickel, T., Eickemeier, P., Hansen, G., Schlömer, S. and von Stechow, C., Eds., IPCC Special Report on Renewable Energy, Sources and Climate Change Mitigation, Cambridge University Press, Cambridge, New York, 535-608.

https://doi.org/10.1017/CBO9781139151153.011

[3] Anon (2014) Power Generation: Facts \& Figures. Volta River Authority Website. https://www.vraghana.com/resources/facts

[4] Mukasa, D.E., Mutambatsere, Y. and Arvanitis, T. (2013) Development of Wind Energy in Africa. Working Paper Series No. 170, African Development Bank, Tunis.

[5] Ahmad, A. (2016) Wind Energy. https://www.slideshare.net/avaise/wind-power-69583552

[6] Adedipe, O., Abolarin, M.S. and Mamman, R. (2018) A Review of Onshore and Offshore Wind Energy Potential in Nigeria. IOP Conference Series: Materials Science and Engineering, 413, Article ID: 012039.

https://doi.org/10.1088/1757-899X/413/1/012039

[7] International Renewable Energy, Agency, Abu Dhabi (2013) Africa's Renewable Future: The Path to Sustainable Future. https://doi.org/10.4324/9781315074436

[8] Baban, S.M.J. and Parry, T. (2001) Developing and Applying a GIS Assisted Approach to Locating Wind Farms in the UK. Renewable Energy, 24, 59-71. https://doi.org/10.1016/S0960-1481(00)00169-5

[9] Yahaya, H., Luka, E.G., Onuk, E.G., Salau, E.S. and Idoko, F.A. (2013) Rice Production under the Youth Empowerment Scheme in Nasarawa State, Nigeria. Journal of Agricultural Extension, 17, 167. https://doi.org/10.4314/jae.v17i2.21

[10] Bobeck, M. (2017) A GIS-Based Multi-Criteria Decision Analysis of Wind Farm Site Suitability in New South Wales from a Sustainable Development Perspective. Master Degree Thesis, Master in Geographical Information Science, Department of Physical Geography and Ecosystem Science, Lund University, Lund.

[11] Watson, J.J.W. and Hudson, M.D. (2015) Regional Scale Wind Farm and Solar Farm Suitability Assessment Using GIS-Assisted Multi-Criteria Evaluation. Landscape and Urban Planning, 138, 20-31. https://doi.org/10.1016/j.landurbplan.2015.02.001

[12] Aydin, Y.N., Kentel, E. and Duzgun, S. (2010) GIS-Based Environmental Assessment of Wind Energy Systems for Spatial Planning: A Case Study from Western Turkey. Renewable and Sustainable Energy Reviews, 14, 364-373. https://doi.org/10.1016/j.rser.2009.07.023

[13] Malczewski, J. and Rinner, C. (2015) Advances in Geographical Information Science. Springer Science + Business Media, New York.

[14] Malczewski, J. (2004) GIS-Based Land-Use Suitability Analysis: A Critical Overview. Progress in Planning, 62, 3-65. https://doi.org/10.1016/j.progress.2003.09.002

[15] Malczewski, J. (2006) GIS-Based Multicriteria Decision Analysis: A Survey of the Literature. International Journal of Geographical Information Science, 20, 703-726. https://doi.org/10.1080/13658810600661508

[16] Drobne, S. and Lisec, A. (2009) Multi-Attribute Decision Analysis in GIS: Weighted Linear Combination and Ordered Weighted Averaging. Informatica, 33, 459-474.

[17] Steinar, F. (2006) The Essential Ian McHarg: Writings on Design and Nature. Island Press, Washington DC.

[18] Carver, S. (1991) Integrating Multi-Criteria Evaluation with Geographical Informa- 
tion Systems. International Journal of Geographical Information Systems, 5, 321-339. https://doi.org/10.1080/02693799108927858

[19] Baniya, M.S.N. (2008) Land Suitability Evaluation Using GIS for Vegetable Crops in Kathmandu Valley/Nepal. Doctoral Dissertation, Humboldt University, Berlin.

[20] Saaty, R.W. (1987) The Analytic Hierarchy Process-What It Is and How It Is Used. Mathematical Modelling, 9, 161. https://doi.org/10.1016/0270-0255(87)90473-8

[21] Saaty, T.L. (1980) The Analytical Hierarchy Processes. McGraw Hill, New York.

[22] Brower, M.C. (2012) Wind Resource Assessment. A Practical Guide to Developing a Wind Project. Wiley, Hoboken. https://doi.org/10.1002/9781118249864

[23] Australian Greenhouse Office \& Australian Wind Energy Association (2004) Wind Farm Siting Issues in Australia. Prepared by Sustainable Energy Australia for the Australian Wind Energy Association and the Australian Government's Greenhouse Office. https://senergyaustralia.com.au/faq/

[24] Hansen, H.S. (2005) GIS-Based Multi-Criteria Analysis of Wind Farm Development. In: Hauska, H. and Tveite, H., Eds., ScanGis 2005: Proceedings of the 10 th Scandinavian Research Conference on Geographical Information Science, Department of Planning and Environment, Stockholm, 75-87.

[25] Bennui, A., Rattanamanee, P., Puetpaiboon, U., Phukpattaranont, P. and Chetpattananondh, K. (2007) Site Selection for Large Wind Turbine Using GIS. PSU-UNS International Conference on Engineering and Environment-ICEE-2007, Phuket, 10-11 May 2007, 184-561.

http://www.uni.edu/apetrov/wind/Weighted/Bennui2007.pdf

[26] Zadeh, L. (1965) Fuzzy Sets. Information and Control, 8, 338-353. https://doi.org/10.1016/S0019-9958(65)90241-X

[27] Jain, P. (2011) Wind Energy Engineering; McGraw-Hill, New York.

[28] Tegou, L.I., Polatidis, H. and Haralambopoulos, D.A. (2010) Environmental Management Framework for Wind Farm Siting: Methodology and Case Study. Journal of Environmental Management, 91, 2134-2137. https://doi.org/10.1016/j.jenvman.2010.05.010

[29] Van Haaren, R. and Fthenakis, V. (2011) GIS-Based Wind Farm Site Selection Using Spatial Multi-Criteria Analysis (SMCA): Evaluating the Case for New York State. Renewable and Sustainable Energy Reviews, 15, 3332-3340. https://doi.org/10.1016/j.rser.2011.04.010

[30] Nelson, V. (2013) Wind Energy, Renewable Energy, and the Environment. 2nd Edition, CRC Press, Boca Raton. 